\title{
"Causa di Stravaganze": Order and Anarchy in Domenico Gargiulo's Revolt of Masaniello
}

\author{
Christopher R. Marshall
}

In July 1647 , the Neapolitan populace rose in arms against the government of the Spanish viceroy. The revolt is named after ics first leader, Masaniello, a poor fisherman in his twenties whose meteoric rise to fame was matched only by his rapid fall from favor with the Neapolitan people and his assassination ten days after the insurrection began. Masaniello's followers were opposed by the combined forces of the Neapolitan aristocracy and the Spanish administration, led by Philip IV's illegitimate son Don Juan of Austria, who eventually succeeded in entering the city in April 1648. He quickly suppressed the rebellion and restored che status quo, bringing to a close what, from the point of view of the establishment, would be remembered thereafter as an infarmous nine months of violence and misrule.

The resolt's origins predate by many years its flashpoint in the summer of $1647 .{ }^{1}$ By the early seventeenth century Naples had swollen to a teeming and in many respects unmanageable population of three hundred thousand, making it the secondlargest and most densely inhabited city of Europe, after Paris. The flood of migration from the provinces was encouraged in great part by the viceregal decision to exempt the city from direct taxes, while at the same time increasing the burden of taxation on the provinces and continuing to maintain in the city what the administration judged to be (unwisely, as it transpired) a less politically sensitive policy of indirect taxation. This urban influx added considerable strain to an already stretched metropolis. The philosopher Tommaso Campanella, for example, estimated that no more than a sixth of the Neapolitan population worked. Although probably exaggerated, his words attest to the growing recognition of a volatile urban underclass, living more or less hand to mouth and referred to disparagingly as either the canaille (canogian, pack of dogs, rabble) or the laxaruses (lazani), a term originally reserved for lepers but now extended to the poorest of the poor. ${ }^{2}$ For the chronicler Giulio Capaccio, this "miserably, beggarly, and mercenary folk ... the dregs of humanity" were to be identified as inveterate malcontents, responsible for "all the tumult and risings in the city" and incapable of being controlled "otherwise than by the gallows." 9

The immediate trigger for the revolt was the decision, taken by the viceroy of Palermo on May 20, to abolish the tax on fruit in a bid to calm popular unrest. As the news spread during the following weeks, the Neapolitan populace came increasingly to demand the same concession in insistent and occisionally violent terms. The moment for rebellion came on Sunday, July 7, the Feast of the Vingin of the Carmine, when the populace forcibly claimed this right by evicting the tax collectors making their rounds of the stalls of the fruit and vegetable market in the Piazra del Mercato. This apparently spontaneous protest rapidly escalated into a full-scale insurrection, which spread throughout the kingdom of Naples and captured the imagination of Europe, particularly England, which saw a parallel between the Neapolitan rising and its own political and social disturbances. ${ }^{4}$

In the years immediately following the revolt three picures of the rebellion were painted in Naples by Domenico Gargiulo, also known as Micco Spadaro. Two small paintings (12\% by $17 \%$ inches [ 32 by 44 centimeters] and $11 \%$ by 15 inches [29 by 38 centimeters]) depict individual incidents, while a third more comprebensive treatment ( $49 \%$ by $69 \%$ inches [126 by 177 centimeters]) synthesizes in one canvas a sequence of events in the Piazza del Mercato (Figs. 1-3). The last picture provided the direct model for a painting by Carlo Coppola, Gargiulo's associate and sometime imitator, that depicts Don Juan's triumphal entry into the Mercato on April 8 (Fig. 4) ${ }^{5}$ The Piazra del Mercato also forms the focus of a fifth picture of the event, produced in Rome by Michelangelo Cerquozai and Viviano Codazi, the latter of whom had recently arrived from Naples, possibly as a result of the disturbances (Fig, 5), ${ }^{6}$

The pictures represent an important carly stage in the evolution of history painting. from the Renaissance and Baroque definition of istona as a canonical subject from the Bible, mythology, literature, or ancient history to the depictions of contemporary political events by David and Goya, among others. They would accordingly have been appreciated in their own day as strikingly novel rather than as part of a clearly defined visual tradition. Gargiulo's eighteenthcentury biographer, Bernardo de Dominici, perceived them in these terms. He describes Gargiulo's Piara del Mencato during the Rnoult as "not only marvelous, but a work of wonder," a phrase he borrowed from the seventeenth-century biographer Filippo Baldinucci's description of Cerquozxi and Codazzi's painting of the event. ${ }^{7}$ The continued challenge that they pose to attempts at classification has been recognized recently in the conclusion that they "lie somewhere between the popular imagery of prints and the elevation of contemporary events into grand-style history painting. "8

These continued difficulties of classification are partly attributable to the fusion in the paintings of traditionally distinct forms of imagery, Gargiulo's Piazta del Mercato daring the Reavit, for example, has been painted in the imposing dimensions the artist normally reserved for his religious paintings." Its emphasis on the unidealized life of the street, on the other hand, aligns it more closely with the generally smaller and considerably lower-ranked categories of genre and landscape painting in which he was also specializing during these years. To this blend has been added an awareness of other recent developments in the so-called minor genres of painting. The battle scenes of his teacher, Aniello Falcone, for example, share with the Piaza a del Mercato during the Rruot the employment of an elevated viewpoint above a 
1 Domenico Gargiulo, Plazra del Merato during the Rewoll of Macaxielle, oil on canvas. Naples, Museo Nazionale di San Martino (photo: Luciano Pedicini)

teeming mass of figures, which is inspired, in turn, by the panoramic prints of fairs and other contemporary subjects by Jacques Callot. The architectural paintings of Codazxi, with whom Gargiulo frequently collaborated, are also important for their topographical emphasis.

Cerquozzi and Codazzi's painting may, in fact, slightly predate Gargiulo's, since it was completed by February 1648. ${ }^{10}$ It was, nonetheless, painted in Rome at some remove from the events depicted and displays, as we shall see, a less developed understanding of the revolt's development. Coppola's picture, by contrast, probably postitates Gargiulo's paintings by a few years. (It must date from 1656 onward, since it is paired with a picture of the plague of that year.) It also differs from the Piaza del Mercato during the Revolt in focusing on the single event that concluded the rebellion. Its emphasis on completion-and a correspondingly greater sense of historical distance from its subject-is further underlined by a commemorative inscription in the air above the piazza. The wowering figure of Saint Michael sheathes his sword alongside this inscription like a saint in a votive painting indicating the restitution of order and the passing of a human scourge from the city.

The greater urgency of Gargiulo's response to the event, by contrast, is evident in the compelling force of the highly distressing imagery that he presents. Observing the violently sketchy style and brutal anonymity with which one of the unfortunates in the Execution of Don Giuseppe Carafa is depicted, for example, with his hands tied behind his back and his face buried in the ground, as one figure lunges down on his head and severs it with a knife while another prepares to impale it on a pike, one can well understand why it continues to merit attention. These extraordinary events are presented even more insistently in the Rexwil of Masaniello, in which such horrors are enacted on the sweeping scale of a large gallery painting.

This article will be directed toward resolving three fundamental misconceptions that continue to characterize the literature on these highly important yet still relatively littleunderstood pictures. The Piazza del Mercato duning the Revolt of Masaniello is generally identified as orginally having formed part of a series with two other pictures of contemporary events, The Eruption of Vesumins in 1631 and Piarza Meratello during the Plague of 1656, whereas a little-known inventory of its original owner confirms that it was painted independently of these works. Gargiulo's paintings of the revolt are also commonly interpreted as informal, journalistic notations of contemporary events, a perception that belies both their artfulness and the seriousness of Gargiulo's attempts to 


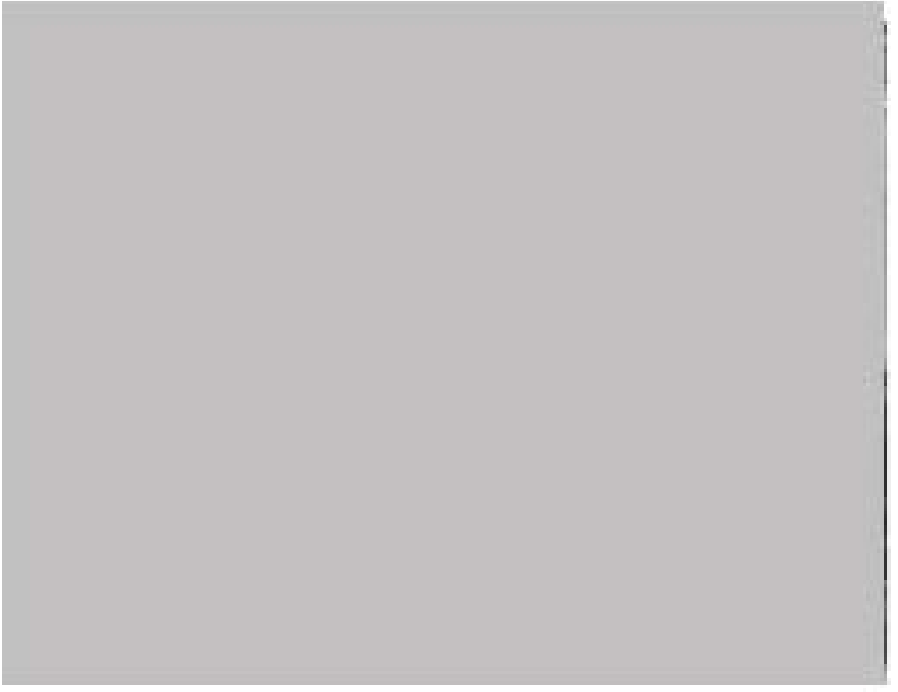

2 Gargiulo, The Punishremt of Thiezes during the Revolt of Masanielio, oil on canvas. Naples, Museo Nazionale di San Martino (photo: Soprintendenza ai Beni Artistici e Storici-Naples)

3 Gargiulo, The Everution of Don Givepple Carafa, oil on canvas. Naples, Museo Nazionale di San Martino (photo:

Soprintendenza Naples)

synthesize the myriad events of the revolt into separate images. They are also frequently interpreted as anti-Spanish in emphasis, whereas an analysis of the political sympathies of Gargiulo's patrons clearly reveals the contrary to be the case.

\section{The Piaza del Mencato during the Revolt of Masaniello and the Inventory of the Collection of Giovanni Battista Capece Piscicelli}

In bis Vite de' pittori, scultori ed architetri napaletani, published in the mid-eighteenth century, Bernardo de Dominici included a detailed and enthusiastic description of a painting then in the collection of Don Antonio Piscicelli, which can probably be identified with the Piazza del Mercato diering the Rezolt of Masaniello. The two small pictures by Gargiulo are probably to be counted among the four small paintings of "various incidents" of the revolt that de Dominici saw in the same collection. A near-contemporary manuscript commentary on the Vite by Onofrio Giannone also mentions the Piazza del Merato during the Rruilt and the four small pictures."

De Dominici's and Giannone's discussions also include descriptions of paintings of the eruption of Vesuvius and the Piazea Mercatello during the Plague of 1656. These are generally identified with Gargiulo's two other pictures of contemporary history, which are today in a private collection and in the Museo Nazionale di San Martino (Figs. 6, 7). The Rewoli of Masanidilo is, accordingly, grouped with these other two pictures as a series, despite the fact that de Dominici and Giannone never describe them as such and despite the fact that they have hitherto only been documented securely to separate nineteenth-century collections. ${ }^{12}$ From this stems the common perception that each painting gains its meaning in relation to the series as at whole, which is taken to present a grand narrative of the three major cataclysms of seventeenthcentury Neapolitan history. The painfully human chaos of a popular uprising is thus redeemed by virtue of its forming part of the divine plan for Naples. According to this interpretation, the Rrvoll is to be viewed as "another kind of natural catastrophe," which, in combination with the other two paintings, "could be contemplated with awe accompanied by a sense of security, for these remarkable and unique events were given controlled, comprehensible order through the artist's representations." 13 A related interpretation perceives all three paintings as an attempt by Gargiulo and his patron "to impose an order on (or find one in) catastrophic events" and concludes that the Ravolt of Masnielle cannot be antiSpanish in emphasis since it forms part of a set with depictions of two natural upheavals. ${ }^{14}$

These views can now be modified by consideration of a little-known inventory of 1690 of the collection of Giovanni Battista Capece Piscicelli, which can be identified with certainty as the forerunner to Don Antonio Piscicelli's painting collection subsequently viewed by de Dominici and Giannone, since the document records many of the paintings that they subsequently describe. ${ }^{15}$ The inventory lists the paintings located in the family's "casa palatiata," situated behind the monastery of SS. Apostoli, shordly after Giovanni Battista Piscicelli's death in August 1690. It forms part of the "adhitio hereditatis" (acceptance of the inheritance) by the cobeneficiaries of his estate, his sons Nicola, Cristoforo, Francesco, and Domenico, from whom the collection presumably passed by inheritance during the next generation to the otherwise unknown Don Antonio Piscicelli.

Giowanni Piscicelli was an aristocratic member of the Seggio of Capuana, one of the five ancient subdivisions of the established aristocracy of the city, whose membership became closed at the beginning of the sixteenth century. $\mathrm{He}$ was elected by his peers in 1674 to the administrative board of the Casa Santa dell'Annunziata, a financial and charitable institution that included a bank, hospital, church, orphanage, and girl's conservatory. ${ }^{16} \mathrm{He}$ is rarely mentioned in histories of the Neapolitan aristocracy, and the will that might have provided us with further information about him remains, unfortunately, undiscovered. It might at this point be worthwhile asking, therefore, whether this lack of further evidence about Piscicelli and his patronage might leave open the possibility that Gargiulo's pictures of the revolt may have been originally 
4 Cirlo Coppola, The Entrance of Don Juan of Austrin into Napios, oil on canvas Naples, Museo Nazionale di Sin Martino (photo: Soprintendenza Naples)

5 Michelangelo Cerquoser and Viviano Codazzi, The Revolt of Masminilla, oil on canvas Rome, Galleria Spada (photo: Gabinetto Fotogratico

Nazionale-Rome commissioned by another collector and then acquired by Piscicelli on the secondary market sometime prior to 1690 . We can be reasonably certain that this was not the case, however, since the inventory establishes that Gargiulo's pictures of the revolt occupied a central place in Piscicelli's collection, which contains an unusually consistent and chronologically focused group of paintings by artists active in the
1640 s and $1650 \mathrm{~s}$. Conspicuously absent from the collection are works by artists active during the 1660 s through the 1680 , whose presence we would expect were the collection still being assembled at this date. ${ }^{13}$

The pictures of the rewolt, morecwer, served as the centerpieces of a comprehensive collection of Gargiulo's work, which was particularly rich in the landscape and genre 


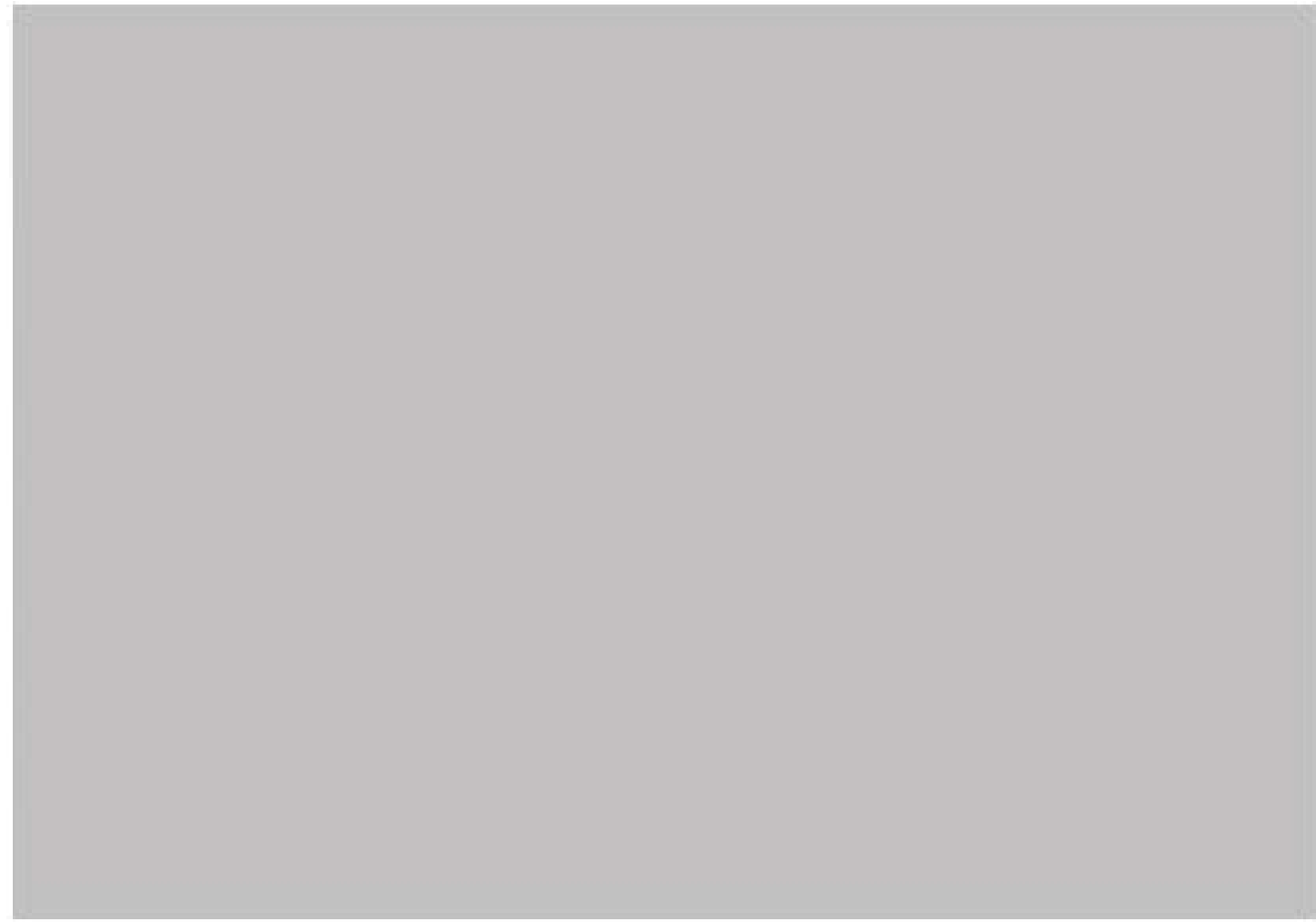

6 Garginlo, The Eruption of Wencuitus in 1631 , sil on canvas, Capua, private collection (photo: Soprintendenza Naples)
7 Gargiulo, Piatza Mercaidlo during the Plague of 1656, oil on canvas. Naples, Museo Nazionale di San Martino (photo: Soprintendenza Naples)

pictures that formed the basis of his reputation. Piscicelli owned no fewer than twenty-nine pictures by Gargiulo, five times more than any of the other artists represented, with a further two architectural scenes by Codazi, which may have included genre fyurine by Gargiulo. His collection covered all aspects of Gargiulo's landscape and genre painting, including landscapes together with coastal views and architectural view painuings. He also collected the work of related specialists, including numerous still lifes by Luca Forte and Giovan Battista Ruoppolo, animal pieces and landscapes by Andrea de Leone, and a pair of battle pieces by Aniello Falcone.

Piscicelli's predilection for the so-called minor genres of painting was highly unusual for its day, given that the bulk of most aristocratic collections still consisted of gallery pictures
8 Gargiulo, Expubsion of the Monglenders from the Temple, oil on canvas. Location unknown (photo: MAS, Barcelona)

of standard religious subjects. ${ }^{18}$ Piscicelli made no concerted effort to collect such painting. Only eight of his fifty-four pictures by known painters were of religious subjects, and he seems to have appreciated some of these at least as much for their landscape and genre imagery as for their subject matter. One of his only two pictures of religious subjects by Gargiulo, for example, illustrates this. It can be identified with a painting of the Expulsion of the Moneylenders from the Temple containing an expansive landscape background and architectural setting, which would have particularly appealed to Piscicelli (Fig. 8). ${ }^{10}$ The influence of genre intagery in the picture has recently also been emphasized in the comment that it contains "an infinite number of situations and details taken from everyday life." ${ }^{\prime 20}$ Piscicelli's inventory confirms, 


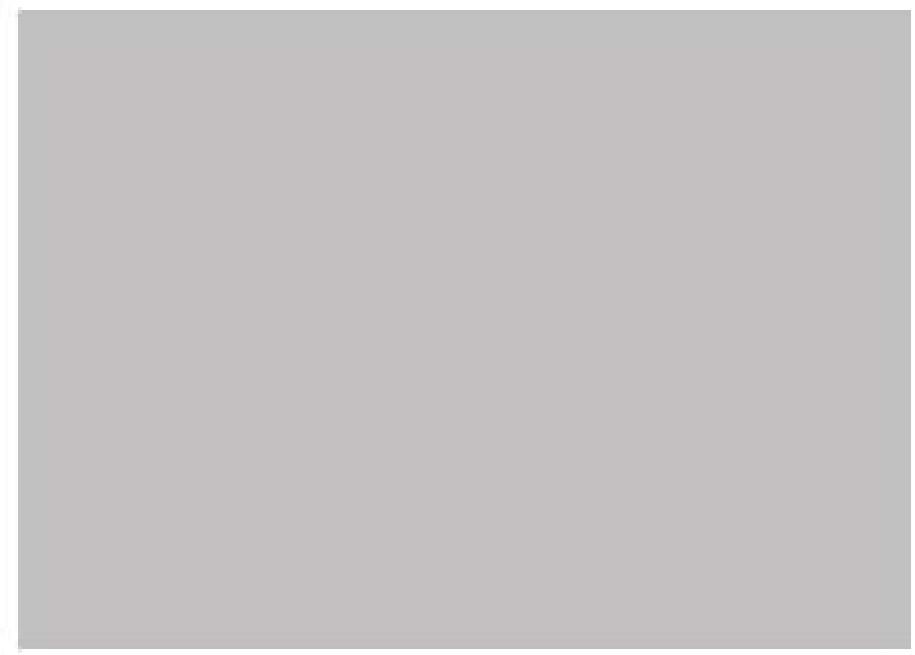

9 Gargiulo, Landscape avich Waskeroomen, oil on canvas. Naples, private collection (from Sestieri and Dapri, 2388)

moreover, the recent reattribution of the architectural elements in the picture to Gargiulo alone, rather than to Codazzi, to whom it was attributed by de Dominici.

Among the largest, and certainly the most unusual, of the pictures in Piscicelli's collection was "A painting of the Rewolution by Spadaro," measuring five by seven Neapolitan palmi, which corresponds with the dimensions of the painting now hanging in the Museo Nazionale di San Martino (Fig, 1; App., item 20). The Revit originally hung in a small room with only eight other pictures, including four small landscapes by Gargiulo and two medium-size religious pictures by Giordano. The four small paintings of incidents of the revolt mentioned by de Dominici are probably to be identified among a group of fourteen small "capricci" (meaning that they were of various subjects of the artist's own composing $)^{21}$ which hung in an adjoining room (App., item 12).

The dimensions of these caprica correspond with the dimensions of the Punishment of Thiores and the Exicution of Don Grusepfe Carafa and are highly unusual for Gargiulo. Similar dimensions, which appear only very rarely in inventory references to Gargiulo's work, ${ }^{22}$ occur in only one other extant picture by Gargiulo: the recently published Lasdscape with Washeravomen (Fig, 9). This painting also shares correspondences with the subject matter of the Punishment of Thioves and the Execution of Don Giuseppe Carafo. ${ }^{23}$ Like them, it emphasizes the violent lawlessness of the Neapolitan populace, albeit on a more domestic scale, since it includes the incident of a woman chasing two would-be thieves with a stick. It also relates closely to the unusually sketchy style of the Pusishment of Thirces and the Execution of Don Giuseppe Carafa. We might be justified, therefore, in tentatively identifying it as another of the capricci in Piscicelli's collection.

Piscicelli must have had a pronounced interest in the revolt, since he hung his cafricci in close proximity to small portraits by Gargiulo and Jusepe de Ribera respectively of Masaniello and Don Juan (who is identified in the inventory as "il Reggente"). Piscicelli's picture of Masaniello would have probably resembled the recently published small portrait attributed to Gargiulo's associate Onofrio Palumbo (Fing. 10 ), while the latter picture would have related closely to
10 Atrributed to Onofrio Palumbo, Masaniella, oil on coppec Naples, Museo Nazionale di San Martino (photo: Soprintendenza Naples)

Ribera's famous equestrian portrait of Don Juan, which is now in Madrid. ${ }^{24}$

The Eruption of Vesuvius and the Plague of 1656 did not hang with the Piasza del Merato during the Resoit of Masaniello, nor do they figure elsewhere in the inventory. They must, therefore, have entered the collection sometime during the ensuing sixty years between the compiling of the inventory and the publication of de Dominici's Vic. Giovanni Battista's heirs may possibly have acquired them from the collection of the leading official of Naples, the ragenie (regent) Stefano Carrillo y Salsedo, since we know that Carrillo y Salsedo commissioned pictures of this kind and that only part of his significant collection passed to his heirs in 1697 , shortly before its dispersal on his death in $1698 .^{25}$ They were not, in any event, the only additions to the collection during these years. De Dominici elsewhere describes in Antonio Piscicelli's collection a painting by Salvator Rosa depicting the martyrdom of Saint Januarius in Solfatara, which can be identified with a little-known painting dating to the mid-1630s (Fig 11). ${ }^{26}$ No paintings by Rosa appear in the 1690 inventory.

The Piscicelli inventory confirms the weight of the independent evidence to suggest that the Reowl of Masaniollo was painted separately from the Eruption of Vesuvius and the Plogue of 1656 . The Rovalt is, in the first instance, to be distinguished from the Eruption and the Plague on stylistic grounds. The most recent attempt to date it places it between the late 1640 s 
11 Attributed to Salvator Rosa, Martydom of Soint Jenwarris. Location unknown (photo: Warburg Institute, London)

and very early $1650 \mathrm{~s}$, about a decade prior to the Plague, while Alfonso Pérez Sánchez's dating of about $1656-60$ for both the Enuption of Vesuvius and the Plague of 1656 also seems reasonable, 27 The pairings or groupings of Gargiulo's pictures of contemporary events cannot, in any event, have been regarded as integral to each painting's meaning, since we know from the early sources that Gargiulo painted them either singly or in differing combinations according to the wishes of his patrons. In the eighteenth century, for example, the Caracciolo di San Vito family possessed a now-lost painting, or paintings, of the Rewit of Masaniello together with a picture of the plague, while the previously mentioned Stefano Carrillo y Salsedo is also known to have sent versions of the Eruption of Vestrius and Rexwlt of Masaniello to Spain. 92 The 1690 inventory thus provides further confirmation of the fact that the early owners of Gargiulo's now-lost pictures of contemporary events possessed them in differing combinations. A painting of the eruption of Vesuvius might have hung alongside a painting of the plague or of the revolt of Masaniello or by itself, depending on the preference of the patron.

This new information clarifies a final, and more fundamental, distinction between the Rrvalt of Masariello and the other two pictures. The Rewll differs from the Eroption and Plogue in the framework for interpreting events that it offers the viewer. In both the Enuption and the Plague, natural disasters are at the point of being averted through the vigorous intercession of heavenly presences. In the former, Saint Januarius moves decisively, and miraculously, to halt the lethal flow of lava. In the latter, the Virgin intercedes with Christ, who demonstrates clemency by allowing an angel to sheathe his sword ia grouping directly inspired by Domenichino's frescoes of twenty years earlier in the Tesoro di San Gennaro of Naples Cathedral). ${ }^{\infty}$ Although undoubtedly cataclysmic and disturbing, these three paintings emphasize, as does Coppola's Entrance of Don faan (Fig. 4), the overcoming of adversity through divine salvation. The man-made events taking place in Gargiulo's Rrovit, by contrast, are beyond the intervention of heaven. ${ }^{\text {so }}$
The Piazza del Mercato during the Revolt of Masaniello and the Events of $16-17-48$

A clearer sense of the broader scope and differing orientation of the Piazza del Mencato during the Revolt can be gained if we compare it more closely with Cerquozzi and Codazzi's interpretation of the event (Fig. 5). For all their similarities, Cerquozzi's treatment of the revolt is worlds removed from Gargiulo's. Although the painting is not merely humorous, Cerquozzi's interpretation appears to have been dosely informed by a sense of the ridiculous,

This aspect of the painting bas attracted the attention of some recent commentators. Laura Laureati has interpreted the painting as a mock-heroic "anti-Spanish satire," while Wendy Roworth has recently observed that the figure of Masaniello depicted "[a]stride his little white horse plunging through the crond before his army of ragged urchins . . may be seen as a small, perhaps comic Alexander the Great in battle." 31 These interpretations are strengthened by certain elements within the painting. The grinning figures behind and beside Masaniello, the dog standing guard against the fleeing tax inspectors, the contrast between the animated figures and the impassive farm animals, most notably the giant black pig poised to eat from the overturned basket of figs that has just triggered the revolution, not to mention the inherent ridiculousness of a revolution precipitated by a fight over figs. All these elements can be described as comical without strain.

Cerquozzi's burlesque treatment of the humiliation of the representatives of the viceroy is in keeping with the political sympathies of his patron, Cardinal Bernardino Spada, a prominent supporter of the French faction at the papal court. ${ }^{\text {s2 }}$ It may also be attributable to Cerquozzi's lack of understanding of the full political and social dimensions of the chaotic events that were unfolding in Naples even as he worked on the painting. Cerquozzi probably relied for his information on one or two eyewitnesses to the revolt. He may have had his account from Codazzi. He may, alternately, have had access via Cardinal Spada to the dispatches sent to Pope Innocent $\mathrm{X}$ by the archbishop of Naples, Cardinal Ascanio Filomarino, 33 Either way, he could not have had more than limited information about the revolt, which was still far from being resolved by February 1648 .

This lack of detailed knowledge of the episodes, or their broader political significance, may help to explain Cerquozzi's decision to focus on the relatively straightforward genesis of the revolt in the tax collectors' eviction from the Piazza del Mercato. Whatever its motivation, the result is a genre painting containing an only partially realized and integrated recounting of a current political event." The illustration of a topical popular uprising is set within the framework of a conventional, generalized market scene. The majority of the figures attending the market remain totally oblivious to the momentous incident taking place in the foreground. While it would be, perhaps, unduly harsh to describe the painting as intellectually and politically impowerished, it is certainly superficial. 55

Gargiulo's interpretation demonstrates a much greater depth of political insight. ${ }^{56}$ In contrast to Cerquozzi, Gargiulo 
has taken pains to suppress the burlesque humor that surfaces occasionally in his other genre paintings. Gone are the figures straining as they defecate in a corner of the scene, the old women chasing thieves, the thieves picking the pockets of gypsy fortune-tellers, the urchins fighting, and the horses attempting to copulate in the street, scattering the wares in the process. (The last four incidents are depicted in the otherwise closely related Market in the Pinaza del Merato, ${ }^{57}$ ) In the Rroblt, Gargiulo allows for no such anecdotal humor.

Gargiulo has, instead, condensed into one canvas a number of events, mostly from the initial stages of the revolt between July 7 and 16. Commentators from de Dominici onward have stressed the degree to which the scenes depicted in the painting remain faithful to the early accounts of the revolt. ${ }^{3+}$ By using these accounts as a guide, it is possible to isolate from the scemingly confused multitude of figures a carefully constructed narrative sequence delineating the main incidents that unfolded in Naples during the early days of the revolt. $^{39}$

Gangiulo's narrative of the revolt commences with the eviction of the tax collectors from the Mercato. This incident is not treated as the central focus, as it had been in Cerquoz$z i$ 's picture, but is rather relegated to a small pocket of activity in the left background, Directly behind this, Masaniello is depicted on a temporary stage erected for popular entertainments, with his arm raised, calling out the civil militia. His address signaled the point at which the uprising changed from the more or less spontaneous riot of the first day into an organized, largessale rebellion, ${ }^{40}$ The remainder of the painting is devoted to the events that followed Masaniello's call to arms. Armed groups, some carrying standards and beating drums, congregate at various points in the piazza. One of the groups is composed of women, a novelty that merited de Dominici's particular attention. ${ }^{41}$

The civil militia's response to Masaniello's call, beginning on the Monday and lasting the next few days, was to loot and burn approximately sixty palaces belonging to some of the most prominent representatives of the Spanish administration (most of whom were members of the local aristocracy). In depicting these incidents, Gargiulo has overcome the problem of alluding to events that occurred beyond the Piazza del Mercato by representing the subsequent moment when the loot was transported back to the Mercato for distribution to the populace. He depicts a file of three carts, loaded with booty and surrounded by figures, which makes its way from the right foreground into the back of the piazza, where a large pile of chests, fabrics, and even paintings is accumulating.

At the end of the first few days, the Neapolitan people appeared to have gained the upper hand. The viceroy had fled the Palazzo Reale and left the city open to the will of the people. On Wednesday, July 10, an attempt to assassinate Masaniello, to massacre a large number of his followers, and possibly even to poison the cisterns of the city had been baunched in the Chiesa del Carmine (which is depicted in the upper right of the picture). It had been defeated, and the probable mastermind of the plot, Don Giuseppe Carafa dei duchi di Maddaloni, the notorious baron and cultivated collector, had been captured and beheaded by the militia. This significant early act of aggression against the Neapolitan aristocracy may be alluded to in the right foreground of the Roolt, where an armed group rushes into the piazra bearing on a pake a mustachioed head that is similar to the one depicted in Gargiulo's smaller picture of the Exontion of Dow Giuseppe Carafa. ${ }^{\text {a }}$

In the Revol, Gargiulo depicts the populace at the moment of its greatest power in almost emblematic form by concentrating on the figure of Masaniello, who reappears in the foreground. In the place of the humble fisherman in the left background is a figure of almost mythic power and preeminence. Masaniello is now the people's "king" of Naples, a status he was to enjoy for the few days remaining to him before the mounting of a second, and this time ultimately successful, assassination attempt in the cloister of the Chiesa del Carmine on Tuesday, July 16.

Masaniello is mounted on horseback and wears a jacket and breeches woven from silver, an appearance at odds with all other portrayals, which depict him in the humble dress of the fisherman. ${ }^{43}$ His "ennobled" bearing and costume present a significant clue, allowing us to identify the precise moment indicated in the painting. Writing on July 12, Cardinal Filomarino stressed of Masaniello, "He did not wear any other clothing than a shirt and white canvas fisherman's trousers, choosing to go barefoot and bareheaded: and he never changed from this attire save for his trip to the viceroy. "44 Masaniello is thus depicted as he appeared on Thursday evening, July 11 , when he rode in the silver costume described by the cardinal, Vincenzo de' Medici, and others, together with his confederates and Cardinal Filomarino, in procession to meet the viceroy, ${ }^{45}$ The meeting was a great, albeit temporary, victory for the people. The viceroy granted the rebels their requests to overturn some of the most unpopular taxes and to right other injustices of the administration, which were solemnly ratified in the Chiesa del Carmine. Masaniello may be depicted on his way to the viceroy or, perhaps less likely, on his return, when he made "a fine speech to the people" immediately prior to entering the Mercato. ${ }^{* 5}$ Masaniello's right arm is raised above the crowd in a gesture of authority, probably to be interpreted as a call for salence. He sits upright in his saddle, controlling his rearing horse while directly meeting the viewer's gaze. He is the only figure in the painting who is aware of the audience, a device that further underlines his absolute anthority over the teeming mass around him.

\section{The Political Sympathies of Garginlo's Patrons}

Thus far Cerquomi's relatively superficial and comical inter. pretation of the revolt has been contrasted with Gargiulo's faithful and sophisticated delineation of the key events of its first days. This interpretation culminates in the depiction of Masaniello as powerful and resolute. Gargiulo's depiction of Masaniello seems, at first sight, to carry none of the negative invective of the many accounts opposed to the revolt. He does not appear to resemble, for example, the "idol of the Mercato ${ }^{4}$ disparaged in a contemporary play ${ }^{47}$ This, in combination with the breadth and seriousness of Gargiulo's 
delineation of the revolt, might appear to justify an interpretation of the painting as a positive commentary on the revolt.

Rosario Vilari has recently developed an argument along these lines, which, while brief, constitutes the only serious recent attempt to discern the political content of the Rewoll. His discussion of Gargiulo's painting forms part of a wider argument against the conventional interpretation of the revolt as a spontaneous plebeian uprising "without head or tail," as Benedetto Croce expressed it. In place of this view, Villari argues for a renewed understanding of the unjustly neglected participation of bourgeois and intellectual groups. Like the vast majority of Neapolitan painters, Gargiulo was from the middle classes. His painting of the revolt is thus, for Villari, an important visual documentation of this identification with the rebels" aims. It may have been commissioned by one of the intellectuals involved in the resolt, such as the lawyer Don Giulio Genoino, the so-called mind of Masaniello, or Giuseppe Donzelli, the doctor and experimental scientist who composed an early history of the rebellion in response to requests from the revolutionary leaders. ${ }^{\text {th }}$

Villari's argument is directly contradicted by the evidence here presented, which securely establishes the painting's prowenance in a seventeenth-century Neapolitan aristocratic collection. But it also inwolves a deeper and more fundamental misconception of Cargiulo's patrons and their position within Neapolitan society. Gargiulo may have been from the middle classes, but he worked resolutely throughout his career to position himself at the upper reaches of patronage. An examination of his patrons reveals him in this respect as a confirmed painter to the establishment. Without exception, his aristocratic patrons were to be counted among the greatest enemies of the revolt, who were utterly opposed to the aims of the populace and the political sympathies of the revolutionary bourgeois intellectuals nominated by Villari. While little is known specifically of the political allegiances of Giovanni Piscicelli, it is at least clear that he belonged to an established Neapolitan aristocratic family di Seggio, and would thus have been directly threatened by the disturbances of the revolt. The aristocrats of the Soggi were united in their opposition to the spread of any political influence on the part of the populace and the bourgeoisie, "This opposition was based as much on economic factors as it was on traditional enmities of class and power since, by the midsesenteenth century, the aristocracy had come increasingly to share in the administration of the state and thus to profit materially from the systems of oppression against which the populace re belled. One of the most popular, and lucrative, means by which they achieved this was to capitalize on the viceregal policy of selling public revenues in both direct and indirect taxes and lands, the latter of which resulted in the alienation of many towns and properties previously in the royal domain. $^{\text {so }}$

The list of Piscicell's assets included with his inventory of possessions indicates the extent to which he partook of this profit. He drew an annual income of 362 ducats from tax farms (arnendamenti) in the commodities of wine, oil, silk, and flour, together with salt from Pugtia and the income of the customhouse of Naplex. He also enjoyed an annuity of 243 ducats from the base hearth taxes, or fiscali, owed on a number of towns and villages (whiversita) located mainly in the Molise. ${ }^{51}$ These annuities would be equivalent to 12.1 million lire in current terms, according to one recent equation for converting seventeenth-century Neapolitan currency to today's values, but it would perhaps be more prudent to compare it with the wages of two ducats paid per six-day meek in the 1640 s to the stonecutters working at the Certosa di San Martino or with the 25 to 40 ducats commonly paid in Naples for a horse. ${ }^{\text {x }}$

Whichever system of comparison we choose to adopt, it is clear that Piscicelli drew a sizable income from the very taxes that precipitated the revolt. Piscicelli's fortune perpetuated this system of oppression, as did that of a great number of his peers, many of whom thereby earned their inclusion in a list drawn up by the rebels of palaces to be ransacked during the opening stages of the revolt. ${ }^{35}$ The demand for retribution for the perceived injustices of the viceregal taxation system also resulted in the destruction of another institution drawn on by Piscicelli for income, the customhouse of Naples, which was sacked during the first day of the revolt. The above information should thus render clear Piscicelli's antipathy to any suggestion that his pictures of the revolt and its protagonists might contain prorevolutionary messages.

Our knowledge of the personalities of Neapolitan collectors remains, in many instances, limited by the fact that a comprehensive study of Neapolitan patronage has yet to be written (although the groundwork for this task has been laid by the fundamental researches of Gerard Labrot, Renato Ruotolo, and Eduardo Nappi, among others). ${ }^{54}$ From early histories of the Neapolitan aristocracy and other sources, it is nonetheless possible to develop a comprehensive picture of the political sympathies of Gargiulo's patrons. From this can be established clearly the same degree of antipathy to the aspirations of the rebels in the case of the other collectors known to have owned pictures of the revolt and its protagonists.

It would be inappropriate, for example, to attach any anti-Spanish sentiment to the two small portraits by Gargiulo of Masaniello and Gennaro Annese (one of the main leaders of the rebellion after the death of Masaniello), which hung in the Pignatelli collection in the early eighteenth century, The Pignatelli were one of the most influential aristocratic families in Naples, whose members included Antonio Pignatelli, archbishop of Naples and subsequently Pope Innocent XII. As such, their political associations and public loyalties were always firmly linked with the Spanish administration and with the preservation of the status quo.

This can be further confirmed by identifying the numerous Pignatelli family members with high-ranking positions within the Spanish administration. Ettore Pignatelli, for example, was appointed viceroy of Barcelona, while another family member received the senior military appointment of master of the field (moestro di campo) of Catalonia. ${ }^{*}$ Another, Fabrizio Pignatelli, was on close terms with both Philip IV and Don Juan of Austria and served as grand constable of the kingdom (gran contestabile del regno) to Philip IV. Fabrizio spent much of 1647 leading troops aggainst the rebels. In 1654, Philip IV rewarded his services by appointing him viceroy and captain general of Aragon. He eventually died in Catalonia fighting the French. Subsequent Pignatelli family mernbers attained 
comparable prominence at the Spanish court. ${ }^{57}$ The loyalty of the Pignatelli to Spain and their antipathy toward the aims of the revolutionaries would thus have been beyond question.

The same degree of loyalty to Spain is evident in Gargiulo's close patron and associate the regent Stefano Carrillo $y$ Salsedo, for whom Gargiulo painted versions of the Eruption and the Revalt. Carrillo, who was of Spanish descent, spent his career in the service of successive viceroys. His brother in Madrid, to whom he may have owed his political advancement and to whom he bequeathed the better part of his collection, was gentleman of the privy chamber (gentiluowo di camera) to Don Juan of Austria. Carrillo was, moreover, dedicated to fighting sedition and lawlessness. As superintendent of the countryside (sopriniendente alla campagna) in the $1660 \mathrm{~s}$ and $1670 \mathrm{~s}$, he was noted for his success in combating the banditry that was rife in the countryside, ${ }^{50}$

There can be no question, therefore, that Carrillo might have commissioned his now-lost version of the Revolt as an anti-Spanish commentary. The opposite must, in fact, have been the case, since he is said to have commissioned versions of the Revolt and the Eruption for export to Madrid, presumably as royal gifts, in order to bring merit upon himself at the Spanish court ${ }^{59}$ Clearly, therefore, Carrillo's painting of the Revolt cannot be interpeted as representative of any "distance ... separating the people of Naples from the Sparish Monarchy," as Villari asserts, but rather can only have been commissioned as an antipopular, pro-Spanish interpretation of the events.

A wider examination of the political sympathies of Gargiulo's other major patrons reveals the extent to which they were equally closely linked to the Spanish administration and opposed to the populace. Ettore Capecelatro, one of Gargiulo's earliest and most dedicated patrons, devoted a long and brilliant career to service of this kind and enjoyed the close confidence of successive viceroys, ${ }^{60} \mathrm{He}$ twice acted as Neapoltan ambassador to Madrid and eventually rose to the position of pro-regent of the Supremo Collaterale Consiglio, the highest judiciary and administrative body in the kingdom. At the time of his death, he stood as one of the preeminent figures of the administration, eliciting fulsome praise from the contemporary commentators Lorenzo Crasso and Nicolò Toppi, among others, ${ }^{61}$ His unswerving loyalty to Spain was even manifested in his collecting, in that he hung his own portrait between likenesses of the viceroy and the Spanish king. As a further indication of his loyalties and attitude toward the populace, it should be remembered that as an unusually unpopular overseer of the customhouse at Foggia, he was the subject of numerous violently negative satires written by the people of Puglia. ${ }^{\text {at }}$

A dedicated patron of Gargiulo's later years, Giacomo Capece Zurlo, served as one of the four judges of the Vicaria loyal to Spain who met in April 1648, to prosecute the rebels. ${ }^{63}$ An early collector, Francesco Marino Caracciolo, principe di Avellino, was one of the leaders of the forces loyal to the viceroy and fought a long campaign against the rebels throughout the kingdom of Naples, ${ }^{6+}$ His zeal was such that he presented to the viceroy a priest whom he had arrested at his feudal seat for disseminating anti-Spanish propaganda. His endeavors against the rebels were specially commended by Don Juan of Austria, ${ }^{65}$ Another associate of Gargiulo, the poet Francesco Dentice, ${ }^{* \sigma}$ similarly spent the revolt stationed at Nola commanding a company of nobility who were defend. ing the city against the rebels. ${ }^{6 i}$ Even Don Giuseppe Carafa, the most popularly despised of aristocrats and the subject of Piscicelli's Execution of Don Gikseppe Carafa, can be identified as one of Gargiulo's earliest and most important patrons. His exceptional collection (which included several pictures by Garginlo and Codazzi) is known to us from an inventory drawn up in 1648 of pictures that had been retrieved after his palace had been sacked "numerous times by the People." 68

The listing of Gargiulo's patrons with clear allegiances to the Spanish administration could be continued. ${ }^{60}$ In fact, only the lawyer Vincenzo d'Andrea, who owned two large architectural paintings by Codazzi and Gargiulo, might conceivably be described as sympathetic to the people's cause. ${ }^{20}$ D'Andrea helped to moderate the ferocity of the repression of the rebellion, but he was certainly no anti-Spanish revolutionary, He was rewarded for his labors after the revolt by the new viceroy, the conde de Oñate, with appoinuments as president of the Sommaria, the financial tribunal of Naples, and superintendent (protedditore generale) of the arsenal of Naples. He thus certainly would not have welcomed the inclusion into his collection of any pictures that might have cast doubt on his political allegiances.

A more tangible impression of the pro-Spanish sympathies of Gargiulo's patrons can be gained by considering the fen overtly political images known to have been commissioned from Gargiulo and his associates. One of these, a little-known drawing by Gargiulo, depicts Don Juan of Austria as the victorious general entering the city gates while the people kneel before him in homage (Fig. 12), ${ }^{71}$ It is similar to, and was probably also influential on, Coppola's previously dis cussed picture of the subject. The technique of the drawing, which, unusually, is highly finished for Gargiulo, suggests that it was a preparatory or presentation drawing for a now-lost painting, a hypothesis that is strengthened by the fact that another drawing in the same technique has also been identi. fied as preparatory to an extant painting. ${ }^{.2}$

Of equal interest is a picture commissioned from Aniello Falcone by Francesco Marino Caracciolo, prince of Avellino, previously mentioned as a collector of Gargiulo's and Codazzi's work (Fig. 13). The painting vividly evokes the linked social and political aspirations of Gargiulo's patrons by emphasizing the continuities of affiliation that spanned generations of the family line. It depicts Francesco's ancestor Cardinal Marino Ascanio Caracciolo, then recently appointed to the post of civilian governor-general of Milan, visiting the imperial encampment during the campaign waged against Francis I by his patron and protector Charles $\mathrm{V}$ in $1536.7 \mathrm{Its}$ message to the contemporary viewer would have been clear. It commemorates the honor and rank attained by a prominent sixteenth-century Habsburg servant as commissioned by a descendant who continues to maintain this allegiance to such an extent that he is prepared to bear arms for it and to denounce those of his own countrymen who stand against it.

Gargiulo's pictures of the revolt of Masaniello form a counterimage to these official declarations of artistocratic affiliation. They also represent, as we have seen, a more 


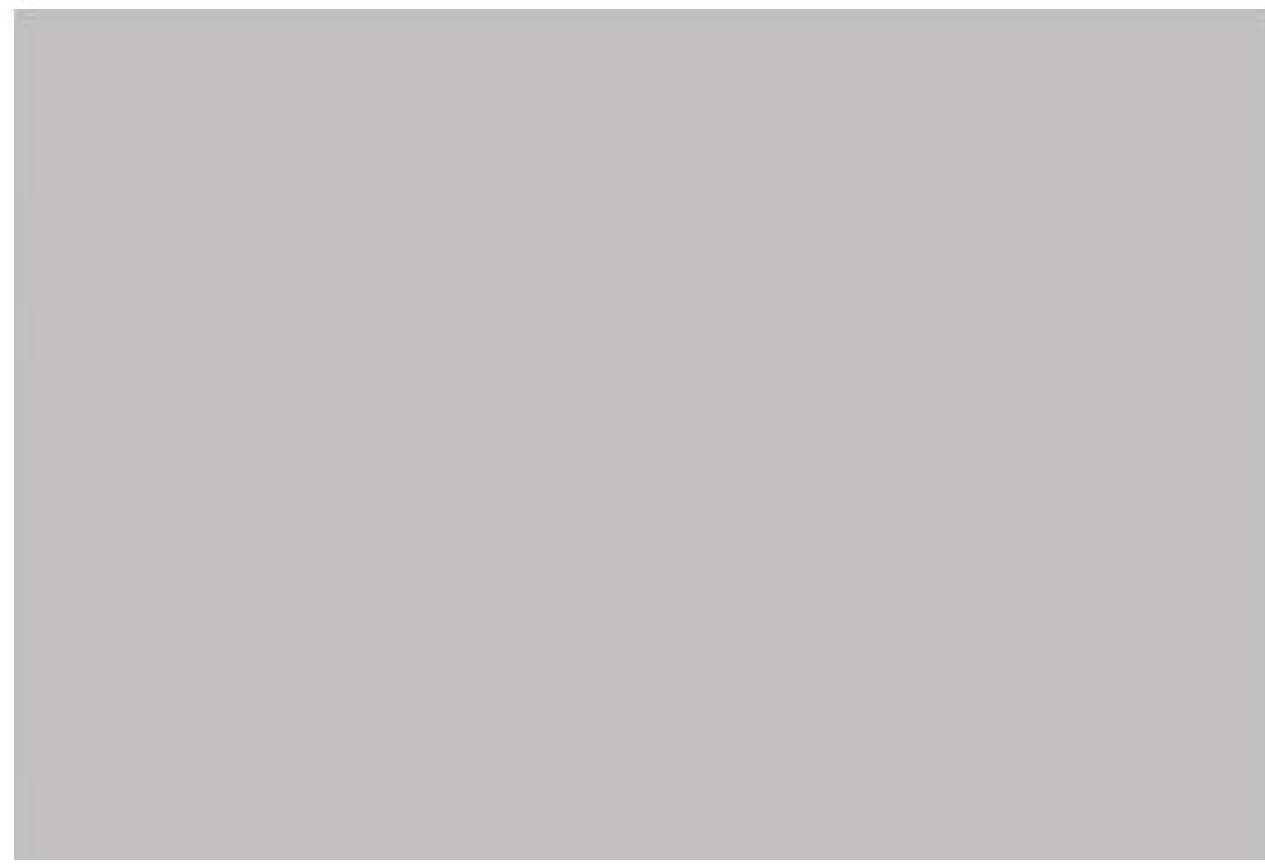

12 Gargiulo, The Entrance of Don fras of Austria iato Noples, Naples, Knight collection (from Sestieri and Dapras, 43)

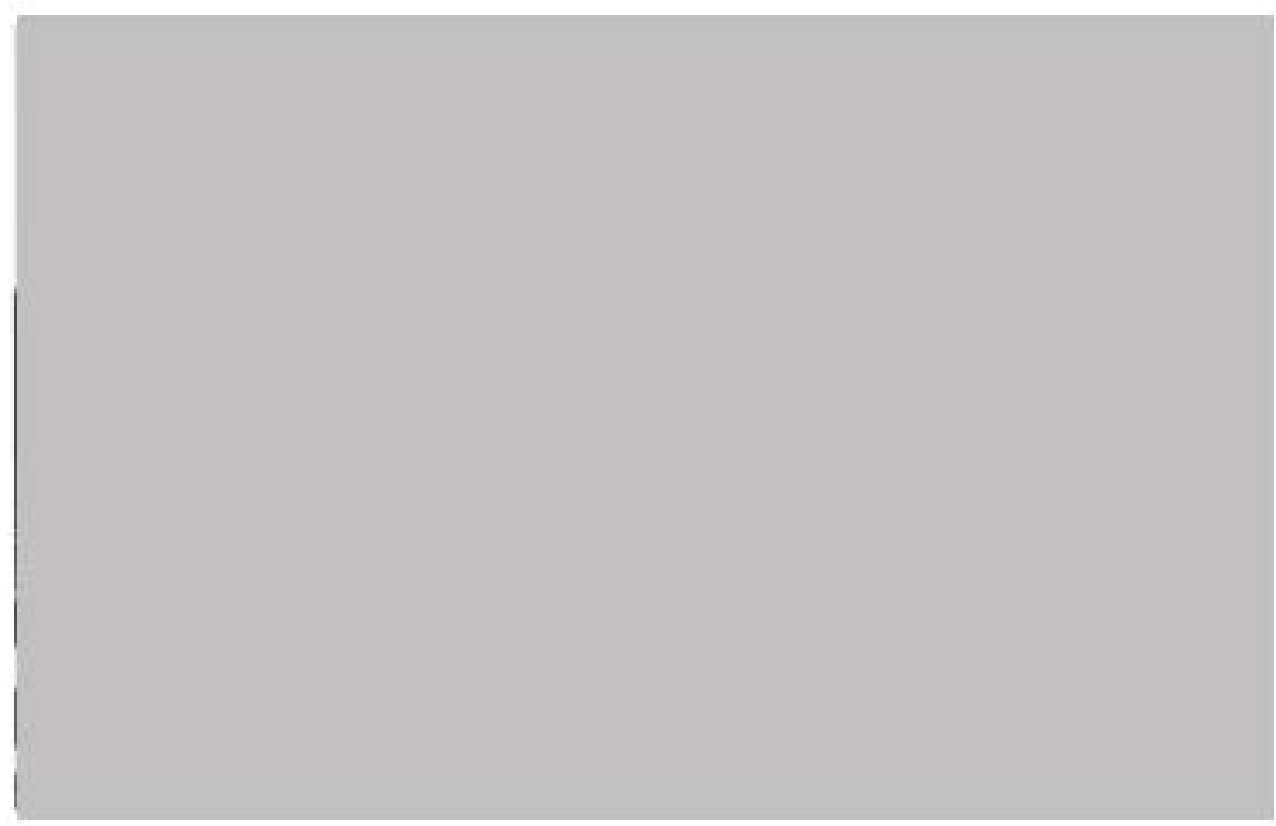

13 Aniello Falcone, Cardinal Marito Caraccialo Visiting the Imperial Army, oil on canvas. Private collection, Rome (from de Vito, "Aniello Falcone \& Co.," Ricenche sul "600 napolrino, fig. 18)

comprehensive attempt to do justice to the complexity of the revolt by recording its different stages of development. In this respect, they diverge significantly from caricatures and other more explicitly negative forms of political imagery. Giovanni Battista Piscicelli evidently appreciated this aspect of Gargiulo's pictures. The portraits of Masaniello and Don Juan of Austria in his collection provide a further indication of his interest in documenting both sides of the opposed camps involved in the rebellion.

Yet for all his evenhandedness and seriousness of intent, Giovanni Battista Piscicelli's understanding of the political dimension of Gargiulo's pictures of the revolt would have remained clear. The previous discussion has confirmed that there can be no question that Gargiulo or his patrons conceived his paintings of the revolt as anything other than pro-Spanish in their outlook. Far from being produced from within the immediate circle of its leaders, they were painted for precisely those enemies of the resolt whose united efforts eventually succeeded in crushing it. However carefully and seriously Gangiulo delineated the revolt, his underlying political motivation can only have been to create a visual record of the evils of popular insurrection.

A further examination of the Pinzza del Mescato during the Rowilt of Masaniello throws Gargiulo's pro-Spanish attitude toward his subject matter into sharper definition. Displayed prominently in the center of the piazra, behind Masaniello and his followers, is the so-called eptaffio, a monument originally commissioned from Cosimo Fanzago by Masaniello on July 14 to commemorate the accord reached with the viceroy on July 11.74 The monument was to have included a marble base with a list in bronze of the privileges conceded to the people and to have been surmounted by statues of the 
viceroy, Cardinal Filomarino, and Philip IV. As with the figure of Masaniello on horseback, the epitaffio thus serves a central visual and symbolic role in the painting. It encapsulates, within a single image, the wider aspirations of the revolutionaries as initially formulated during their brief moment of ascendancy.

As a symbolic sisualization of the revolution's aims, however, the epitaffio can only have been regarded ironically by those who knew its outcome, since its history encapsulates the failure of the revolt. Fanzago had no sooner commenced work on it when he was halted by a violent uprising that threatened his life and home. ${ }^{75}$ In September, work recommenced on a second, enlarged epitajyo in the center of the Mercato, which was to have included the inscriptions of the amended privileges. Gargiulo has also included the original coitofjo, which was left uncompleted, near the Cappella di Santa Croce behind and to the right of the figure of Masaniello on horsebuck. ${ }^{7 \%}$

The social and political turmoil of the following months prevented the completion of the second efriaffio (both were eventually demolished in December 1652), In the end, the only use to which the epitaffio was put during its brief existence was to display the severed heads of those executed as enemies of the people, ${ }^{\text {Th }}$ Gargiulo depicts it in this manner as it appeared in the later months of the resolt. ${ }^{39}$ It is lined with severed heads and has been used as a dumping ground for a pile of naked, headless bodies, one of which has been hung from a pole.

The epita/fino of the Rewolt is thus, literally, a failed symbol. Far from communicating its origins as an expression of the democratic covenant between the people and the administration, it vividly expresses the principle of anarchy that, from the point of view of the establishment, strongly characterized the rewolt. It is ruinous and grotesquely deformed by the marks of violence that dominate the painting: people being dragged, bleeding and bound, to the mob, and others threatened with pikes, assaulted, and knocked to the ground. Carafa's execution sent shock waves through the ranks of the Neapolitan aristocracy. In the left foreground, a huddled group of anxious figures wearing the cappa ners and goniglia favored by lawyers, bureaucrats, and cavalieriare menaced on all sides by the mob, ${ }^{80}$ Another figure beneath the original phitaffio, dressed in the manner of the populace, is dragged by the foot to the second epitaffo, where he is, presumably, to meet the same fate as the others already executed. The people's ferocity is thus presented as indiscriminate and threatening to all sections of Neapolitan society.

The atmosphere of violence that pervades the painting is combined with an even more insistent impression of disorder of cosmic proportions. Although the painting articulates a carefully constructed sequence of events, the figures participating in these events are positioned in a manner that emphasizes their lack of unity and organization. ${ }^{\text {.1 }}$ Unregimented masses of figures are scattered in random groupings across the painting. In the right foreground, a frenzied mob of frantically gesticulating figures forms a jumble of heads, legs, and arms that collides, in turn, with one of the carts loaded with loot entering the piazca from the opposite direction. The impression of an undisciplined, motley group is reinforced by the ragged clothing worn by most of the figures. A sense of cosmic disorder is further underlined by the manner in which many of the figures appear to reflect the contemporary paradigm of the world turned upside down. ${ }^{\text {A2 }}$ Miserably dressed children carry halherds and accost their superiors in both age and social status; women congregate in armed bands; shopkeepers loot palaces; and a lowly fisherman rides a fine horse and dresses in an ostentatiously elaborate costume.

Such is the nature, Gargiulo suggests, of the bizarre and threatening social and sexual distortions that accompany the overthrow of the established order. The behavior of the people, when empowered, degenerates into acts of perversion, violence, and mob rule. As such, the Piazsa dd Merato during the Rowlt of Masaniells conforms to the conventional interpretation of the revolt as demonstrating the degree to which the people were fundamentally capricious and irrational in their actions. This underlying disparaging attitude was adopted even by those sympathetic to the revolutionaries in certain regards. Cardinal Filomarino used the metaphor of boiling liquid to describe the riotous behavior of the people during the early days of the revolt. ${ }^{83}$ The anti-Spanish physician Angelo della Porta interpreted the people's behavior as acts of "strange madness." Della Porta's alternative title to his account of the revolt-Causa di stranaganze (The Reason for the Eccentric Behavior) - perfectly fits the tenor of Gargiulo's interpretation of the revolt.

\section{The Revolt of Masaniello and the Conventions of Genre Painting}

Peter Burke has recently examined the degree to which contemporary narratives of the revolt were preconditioned by conventions of the dignity of history. These conventions did not allow the narrators to make any sense of the people's actions, which occurred outside the parameters of meaningful historical action in an unstable world of irrationality and inchoate fury ${ }^{\mathrm{N}}$ Gargiulo's paintings of the revolt seem to have been subject to a directly analogous process of being circumscribed within preexisting conventions of low-life genre imagery.

In paintings with aristocratic and noble groupings, Gargiulo sought to unify and organize his figures in a becoming manner. Speaking of Gargiulo's now-lost Triumph of Cueser, for example, de Dominici noted the presence of "thousands of figures, clothed and armed with Roman propriety, and adorned with various additional embellishments, and so well positioned, that the excessive number did not result in confusion, but each figure distinctly made his own gracious actions." 36 Both Gargiulo's and de Dominici's awareness of the critical requirements of figure groupings was conditioned by their belief that history painting, like written history, should aspire to nobility and idealization. Genre painting represented the converse of this ideal. It was the realm of a lower and more informal style of representation that operated according to a different set of criteria founded on an emphasis on ignoble, burlesque humor and on principles of variety, invention, and anecdotal detail. ${ }^{37}$ 
14 Gargiulo, Trumpi of David, oil on cantass. Sarasota, Fla, John and Mable Ringling Museum of Art

This distinction can be illustrated by comparing the figures in an istoria and in a genre painting by Gargiulo (Figs. 14, 15) ${ }^{\text {sy }}$ The figures in Gargiulo's Triumph of David, which are larger and more carefully characterized than those in his picture of a Fair, closely match de Dominici's description of the Triamph of Caesar Gargiulo has attempted to provide them with both a sense of group cohesion and a distinctness, so that each figure might display its own "gracious actions." By contrast, the figures in the Fain, like the Piarza del Merato during the Rowolt of Masaniello, are scattered in random groups across the canvas. The emphasis is on unidealized variety rather than dignified unity.

De Dominici recognized the inportance of this distinction in his commentary on Antonio Piscicelli's collection. His description of the Reroll, for example, makes no mention of gracious figures or a unified compositional scheme. A response along these lines would have been inappropriate for a picture of this kind. De Dominici is struck, instead, by the disorderly spectacle presented by the "innumerable" and "infinite" Neapolitan masses. He makes no comment on the painting's composition, other than to point out its topographical features, and proceeds, instead, to a detaled, descriptive account of each of the painting's anecdotal scenes. ${ }^{\text {in }} \mathrm{He}$ employs the same framework when describing a painting of a fair by Gargiulo, further underscoring its connection with the Revoit by placing it immediately after his commentary on the Revoit:

He has there likewise painted by the same author a Foir with various and copious inventions. [The artist depicts] He who does business, he who will buy, the loafer who watches goings on, while others listen to the Charlatans and Saltimbanks who perform comedies, and all is executed with very truthful and felicitous imitation. ${ }^{93}$

The viewer should not perceive paintings of this kind from a broad, sweeping perspective, de Dominici suggests, but, rather, should lose himself in the anecdotal details that proliferate thanks to the "copions inventions" of the artist. The figure groupings in history paintings should demonstrate propriety and not "create confusion." Confusion, randornness, ungovernable variety, on the other hand: these are the rightul properties of genre painting, since its subject matter is taken not from the idealized realms of history painting but from the low, ignoble world of the populace.

The violence of the Neapolitan people's actions during the revolt of Masaniello was thus all too easily assimilated within artistic conventions that were informed, in turn, by class 
15 Gargiulo, Fair, oil on canvas. Sorrento, Museo Correale di Terranova (photo: Soprintendenza Naples)

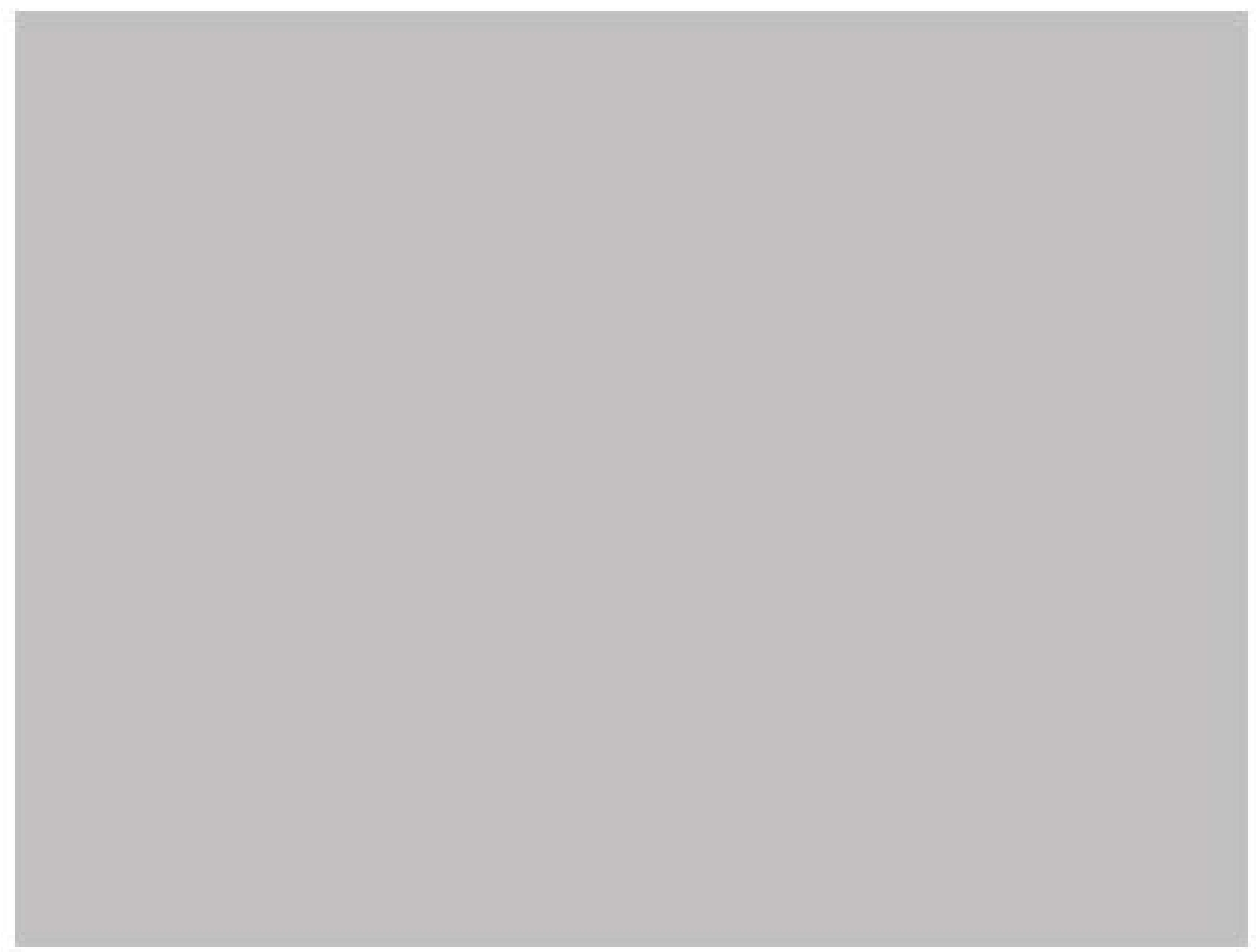

stereotypes. As the most impressive example of Gargiulo's skills as a genre painter, Paolo de Matteis accordingly singled out Gargiulo's paintings of the revolt, above all, his pictures of "Popular, and turnultuous demonstrations," expressed in a most spectacular manner a conventional view of popular disorder, which informed both the social attitudes of the upper classes and the critical status of Gargiulo's genre paintings.

This process is more readily apparent in Giovanni Piscicelli's two small cocprici of The Penishment of Thieves during the Reodt of Masaniello and The Execution of Don Giuseppe Carafa. The paintings depict the rituals of degradation and punishment carried out by the people during the revolt. In one, a group of prisoners is paraded through the streets by a jubilant crowd. The heads of those already executed are carried aloft, while others shuffle to their fate with their hands bound. One prisoner is led on the back of an ass with a paper crown of false gold, a common symbol of treachery." In the second painting, figures rush into view carrying the heads of those just executed. A partly dismembered corpse lies on the ground beside another, depicted at the very instant of decollation. From the left corner, a group of children drag toward Masaniello Carafa's almost naked corpse, beating it as they go. ${ }^{\text {s }}$

The pictures might appear, at first sight, to corroborate recent descriptions that have emphasized their informal, journalistic appearance. They certainly contrast markedly with the carefully orchestrated gracefulness of an istoria like the Triumph of David. The figures rushing in all directions in and out of view in The Execution of Don Giasoppe Canafa, for example, are chaotically uncoordinated in comparison with those in the Triumph of Danid. This effect is heightened by the arbitrary framing of the picture, which, like a hurried snapshot, captures only part of the scene. The frame truncates some of the figures, including a number of the victims of the mob's fury, who might normally have been expected to constitute the focus of the picture.

Yet, it would be misleading to conclude that the pictures are simple documentary transcriptions of unadorned reality. The pictorial devices of disorganized composition and randomly placed frame produce an effect that is every bit as contrived as an istoria, albeit one directed toward opposite ends. In the istonia Gargiulo sought to convey a dignified sense of clarity and timelessness. In these pictures he presents, by contrast, a series of chaotic, fragmentary impressions of recent and spontaneous outbursts of anarchy. Their extraordinarily sketchy technique serves to heighten the sense of confusion by blurring many of the figures in the midst of frenzied motion. The artistic freedom of Gargiulo's loose brushstrokes also has the effect of self-consciously focusing the viewer's attention on the act of depiction. This locates the pictures firmly within the tradition of the macchin or copricio approach to painting, which Gargiulo commonly followed in his small, loosely painted landscapes (Fig, 16), ${ }^{\text {"N }}$ This connection is, indeed, underscored, as we have seen, by their probahle identification as confricci in the 1690 inventory of Piscicelli's collection.

The term macchia (literally, a spot or a stain) was used in the sixteenth and seventeenth centuries to describe the rapidly sketched form of the artist's initial conception, as opposed to the carefully conceived, fully finished image, ${ }^{36}$ while capprocin denoted the approach informing its creation. Ideas of inventive variety and freedom from the customary rules of convention and decorum were central to the caprictio approach. 
16 Gargiulo, Landeape with Ropoids and Trazeless, oil on canvas. Piacenza, private collection (from Sestieri and Daprâ, 245)

But this emphasis on operating outside the rules could be applied in a negative sense. The mado di machiere could also be used to describe an "accidental form," or ill-defined, disordered image beyond the redemption of artifice. ${ }^{\text {Bs }}$ The violence and misrule that so characterize the small paintings of the revolt strongly suggest that Gargiulo, in this instance, drew on this negative aspect of the capricio approach. The chaos and anarchy of the people's actions corresponded perfectly to the appearance of confusion created by a particularly extreme expression of macchietisma.

These negative visions of popular anarchy were to be contrasted with the propriety, order, and stability manifested by the establishment. Gargiulo's later Erupsion of Vestrius (Fig. 6) contains a vivid delineation of this collision of the opposed principles of established order and popular disorder. In the painting, the response of the establishment to the threat of the eruption is unified, decorous, and orderly. The viceroy. civil administrators, members of religious orders, and the aristocracy progress in rows of three and four, carrying lit torches in a group ritual that enables them to project a unified sense of composure in the face of disaster. Their confidence is bolstered by the fact that they hold the instruments of power: the relics of Saint Januarius and other saints, whose aid they solicit to overcome the disaster. The plebeians, on the other hand, remain disempowered and marginalized. They position themselves haphazardly, wherever they can, and crowd the procession in threateningly unstable groups. Lacking all decorum or restraint, they hysterically beseech the members of the procession for deliverance. One figure even licks the ground in a traditional expression of selfabasement still practiced in southern Italy by those seeking divine intervention. 9

The Eruption of Wowius differs fundamentally from Gargiulo's paintings of the revolt in the manner in which the people humbly defer to their superiors and to the socially controlling power of religion. However latently violent and unstable their actions may be, they remain, in this instance, positively channeled into acts of penitence and devotion. In the paintings of the revolt, on the other hand, the negative interpretation that underlies this conception of popular diversity comes dramatically to the fore. The paintings of the revolt present antitheses of the rituals of unity and decorum displayed by the extablishment in the Exuption. In a dramatic reversal of the class interaction in the Eruption, they act out for the aristocratic viewer public manifestations of popular anarchy.

As a spectacular visual reinforcement of a stereotyped conception of the Neapolitan poor, Gargiulo's painting would thus have functioned analogously to the traditional cucoggna. The cuccugna, a staple feature of Neapolitan seventeenth- and eighteenth-century festivities, was one of the few ritualized occasions on which the populace performed en masse for the entertainment of the upper classes. ${ }^{100}$ Although rarely depicted in Neapolitan art, it is given noteworthy visual form in Filippo Falciatore's Cucuagna in the Largo di Palazso (Fig. 17), which is indebted to the Platza del Merato dising the Revolt and other paintings by Gargiulo. ${ }^{161}$ It consisted of an elaborately contrived temporary construction that was loaded with food and wine and then assaulted by the people following a signal from the viceroy. The cuecagna was designed and orchestrated in order to reinforce, in the most vivid and insistent manner possible, the stereotype of the inherent violence and bestiality of the people. It was supplied with live animals, which were tied or, in the case of birds, nailed by their wings to the walls, before being slaughtered by mobs of the poor in a frenzied riot of pillaging. The overabundance of foodstuffs, which were often hung high up and almost out of reach, occasioned fierce, and often lethal, fighting between the participants, who also skirmished with the troops posted to keep them back until the signal for assault came.

The vision of popular anarchy expressed in the Piazza del Macato during the Rantr of Masanidlo is much more serious and comprehensive than the entertainment of the aucogna. Nevertheless, the Rewolt operates in a similar sense as an image of a spectacular public event that has been painted to reinforce the principle of popular anarchy and confusion that underlay aristocratic attitudes toward the people. Like the aucagna, it afforded aristocratic viewers an unforgettable opportunity to see their stereotyped conception of the Neapolitan poor reflected back on a grand scale.

\section{Appendix}

\section{The Inventory of the Art Collection of Giovanni Battista Capece Piscicelli}

The following inventory lists the paintings and other works of art located in the family's "casa palatiata" situated behind the monastery of SS. Apxstoli, shortly after Piscicelli's death in August 1690 . The inventory is reproduced in its entirety except for furniture and household effects, which have been omitted for reasons of space. The transcription follows The Getty Ponevenance Index in assigning a Roman mumeral to each room listed in the inventory, and an Arabic numeral to each of the entries for indixidual works. It preserves the literal spelling, dialectal forms, and punctuation of the original, with the exception of abbreviations, which have been spelled out for clarity unless the meaning of the abbreviation is generally accepted and understood.

ASN, Notai del Seicento, notaio Nicola Antonio Collocola, 
17 Filippo Falciatore, Cuccagna in the Lango di Palasza, oil un canvas. Naples, private collection (Photo: Luciano Pedicini)

scheda 550 , protocollo 20 , ff. $760 \mathrm{v}-763+$ ff. 1-4 allegati al f. $760 \mathrm{lv}$, in The Getly Proumance Index: Cumulative Edition on CD-ROM (Malibu: The J. Paul Getty Trust, 1996), Inv. 1-245:

Adhitio hereditatis quondam D. Joannis baptiste Capicij Piscicelli.

Die secunda mensis septembris 1690 Nepoli hora vigesima 2. ${ }^{\text {a }}$ seu quasi inte Venerabilem Ecclesiam SS, orum Apostolorum. Ad preces Nobàs factas prồ parte Domini D. Nicolai, D. Cristofari, et D. Francisci Capicij Piscicelli Fratrum, dictique Domini D. Nicolai etiam uti procuratoris Domini D. Dominici Capicii Piscicelli similiter eius fratris .... personaliter accessimus ante dictam Venerabilem Ecclesiam, et dum essemus ibidem, ipsi Domini D. Nicolaus, D. Cristofarus, et D. Franciscus nominibus quibus supra, sponte asseruerunt coram nobis mensibus proxime preteritis (sicut Deo placuit) quondam Dominum D. Joannem Baptistam Capicium Piscicellum eorum Patrem vitam cum morte commutasse, ob cuius obitum sequtum ... ipsos Dominos D. Nicolaum. D. Cristofarum, et D. Franciscum, dictumque Dominum D, Dominicum fuisse declaratos filios legittimos, et naturales, ac heredes universales, et particulares dicti quondam Domini D. Joannis Baptiste ex Testamento ... et deliberantes ipsi Domini Fratres ne Hereditas predicta sit eis potius damnosa, quam utilis, et fructuosi, deliberaverunt hereditatem predictam adhire cum beneficio legis, et inventarii, et publicum conficere inventarium de omnibus bonis, et Juribus hereditatis pre. dicte. ... Inventario delli beni remasti nell'hereditä del quondan D. Gáovanni battista Capece Piscicelli.

Una Casa palatiata sita dietro il monasterio di Sant Apostoli detta la Casa grande nella quale al presente habitano deuti heredi nel quarto superiore, et nel primo quarto vi habitano D. Francesco, et Altri di Brancia affittatoli infra annum ...

1. Nel quarto di sopra à man destra vi sono l'jnfrascritue robbe videlicet

1. Dieci Ritratt di Rè, Regine, et lmperatori grandì è piccoli
II. Alla prima camara à man sinistra videlicet

2. Due quadri con cornice indorata intagliata con boschi, marina, e vache di Spadaro di 4 e 5

3. Due altri quadri di palmi sette è cinque è mezzo con boschỉ è marine Vache con cornice jndorata jutagliate di Spadaro.

4. Due altri quadri di 4 e 3 di scaramurze d'huomini di Spadaro con cornice indorata

5. Uno quadro di 4 e 5 con cornice indorata di mano di Spadaro il quale rapresenta la discacciata del tempio con cornice indorata [sic.]

6. Due quadri di 8 ex 4 con caccie di tori e cignali con cornice indorate di mano d'Andrea de Leone

7. Due quadri di mano del Cavalier massimo di 5 è 7 uno di locretia Romana, et laltro della Cleopatra con cornice indorate

8. Due quadri bislunghi di 3 è quattro di frutti con cornice indorata liscia di mano di Ruoppoli

9. Due prospettive di uno è mezzo è due con comice indorate intagliate di mano di Viviano

10. Un giardino, et una marinella di uno in quadro di luca forte con cornice indorate intagliate

11. Quattro quadri di uno in quadro con cornice indorate intaggliate di luca forte

12. Quattordeci quadretti di uno ề mexzo ề uno di capricci di Micco spatare con cornice indorate

13. Un ottangolo piccolo di Masaniello con cornice indorata intagliata di Spadaro

14. Due quadri di 3 c̀ 2 di frutti con cornice indorate intagliate di mano di Ruoppoli

15. Una Giuditta di un Palmo è mezro è due di mano d'Agostiniello [i.e. Beltrano] con cornice indorata intagliata

16. Un ritratto del Reggente di Rivera di due è uno con cornice indorata liscia

17. Due battagtiole d'uno in quatro con cornice indorate intagliate di mano d'Aniello falcone

18. Una lavarina di notte d'uno è̀ mezzo è due sopra pietra, con cornice indorata liscia di mano di Andrea de Lione 
III. Nella prima cammera à man diritta videlicet

19. Due quadri uno di $S$. francesco di mano di Giovanni battistello [i.e. Caracciolo], et altro di Santo Cristofaro di mano di spadaro con cornice indoraca intagliate di palme due è due mezo

TV. Nella Seconda Camera videlicet

20. Uno quadro della Revolutione di mano di Spadaro con cornice d'oro lavorato di 5 è 7

21. Uno quattro di due è mezzo è cinque è mezzo con cornice. indorata intagliata di mano di Giordano che è la probatica pescina

22. Uno quattro di 5 è 7 di mano di Giordano con cornice indorata con la figura di S. Anna, S. Gioachino e la Madonna 23. Quattro quadri di due è mezzo è due con cornice indorata lixcia di prospettive, et altro di mano di Spataro

V. Nel altrat camera videlicet

24. Uno quadro di Sant'Antonio grande di mano di Gtovanni Rjeca con cornice lavorata indorata

25. Uno quadro di Gioseppe Giusto grande con cornice liscia indorata mano di Artemisia

26. Un Santo Gòovanni di 3 è 5 con cornice lavorata indorata di mano di [left blank]

27. Sette Quadri di diverse devotioni e diverse misure con cornice d'oro liscia

28. Uno quadro con una marina di mano di Spadaro con cornice. indorata di 3 è 5

Christopher $R$. Marshall, who received his $P h . D$, in 1994, is a lecturer in art history and tauseuw studies at the University of Melbourne. $\mathrm{He}$ is currently preparing a study of the collexting and maketing of art in sevententheentury Naples ISchool of Fine Arts, Classical Studies and Archaeolog, Universiry of Molbotime, Parkaille, Victoria 3052, Austratiaj.

\section{Frequently Cited Sources}

ASN: Archivia di Stato di Napoli

Berke, Peter, "The Virgin of the Carmine and the Revolt of Slasaniello," Past and Prom/99 (1985): s-21.

Capasso, Barvolonmeo, "Líepitaffio del Sereatn e he fontana della Sellaria," parts 1 and 2, Napsil Nobilissisa fi, no 8 (1897): 118-19; no. 9 (1897): $155-40$.

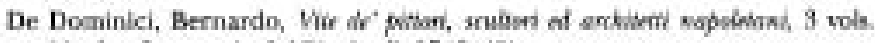
(Naples Stamperta del Bucciardi, 17-20-45).

Forentino, Katia, "La rivolea di Mreaniello del 1647," in Choüd del Serento z Napsil, ed. Silta Casani, exh. cat, 2 vols., Museo di Copodimente and Museo Diego Aragona Pignatelli Cortes, Napies, 1964, vil. 2, 43- 19

Labrot Getrard, Colletions of Panaing is Noption, 3600-1750 [Munict: K. C. Sasur, 1992 .

Marshall, Christogher - Qurll'ammirabie ingegone'; Dumesico Cargiulo and the Productios and Reception ot Neapolitan Baroque Paincinge" PL.D. diss., Uninersly of Melbourne, 1994.

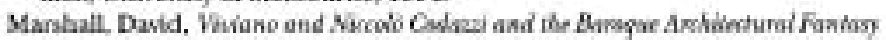
〈Rome: Jandi Sapi, 1993).

Palermo, F., ed, 1846ia, "Documenti sulla storia economia e civile del regno- - camati dal cariegyio degā agenté elel grandaca di Toscana in Napoli

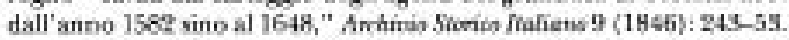

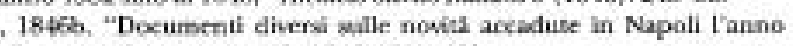

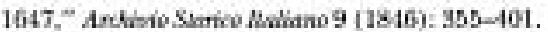

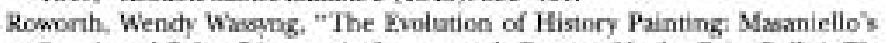
Rewolt and Other Disasters in Seventeenth-Century Naples," Art Rulltin 75, no. 2 (1998): $219-34$

Ronotolo, Renatn, "Collecioni e mecrnati napoletani del XVII sceolo," Napol Nohulisuins 12, no, $4(1975)$ : 118-19, 145-5s,

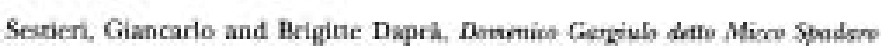

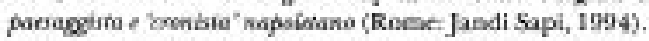

Villari, Rosaria, 7ke Rrewt of Nopks, trans.]. Newell [Cambridge: Polity Press.

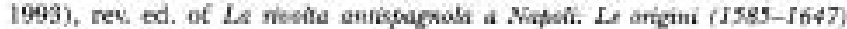
(Bari: Latera, 1967).

\section{Notes}

This article is a revised version of chap. 9 of the author's PL.D. disvertakion IC. Marshall, 1994), It was perestried, in in earlier form, at the 1994 conference of the Art Association of Austratia and at the Bibliotheca Hertaiana, Rome. Research was matle poseithle in gersesons grants from the Lizetse Bentwitch Scholarship Fund and the Arts Faculty Rescarch and Graduate Soxdie Commitice of the Uniwernity of Meloourne, the Italian Ministry of Poreign Affairs, and the Arutralian Posigraduate Research Award Fund Thanks are also due to Mangaret Manion and to David Marshall, Javnie Anderson, Peter

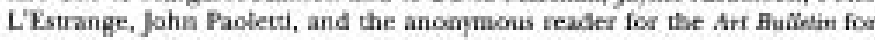
their most helpful comments. I wish, firsily, to recognize the contribution of Gérard Labroc, whose publicalions remain fundamencal to this area asd is whems credit for the disconery and transcripeion of the Piscicelli inventory is due. Unless ocherwise indicaved, translabons are mine.

1. John Hustahle F.llinet, "Revolis in the Spanish Monarchs" in 7he Procowilisions of Resclunioe is Eanty Medrm Eurspe, ed. Robert Foster and Jack Geren (Ratimote, Joths Hopking University Press, 1970\%, 109-90: Burke, B-21; Villari, passim.

2. Benederta Croce, "I 'Iaceari," "in Andowi di eqria Gileotum, vol. 3 (Rari: Laterz, 196-1), 198-205.

3. Gaulio Capaccio, quoted in Benedetso Croce, Hisdon sf the Kingedoe of Napies, tans. P. Frenaye (Chicago Unkersiry of Chicago Press, 197i), 120. Bartalommexa Capases, "Napoli ícscritia nei principe del secolo XVII da G, C.

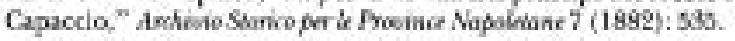

4. For English rexponses to the rewalt, sce Roworth، 230-32.

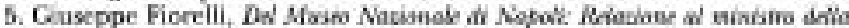
fubthru birusisue (Naples Tipegalia Teliara, 1853), 40; Demetrio Salszaro

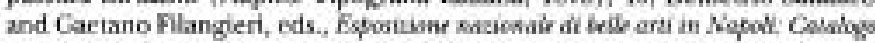

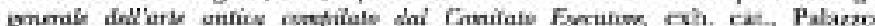
dell'Zsposizione, Naples, 1877, 130 (atributed to Scipione Compagroo); Aldo

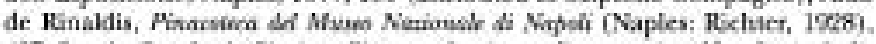
427; Sergio Orvolani, Givrinto Giganie e la pirtura di paesagoso a Napsĭ e in Mah̀e do' 600 of 'gor ed Raflaello Causa (Naples: Moeianino, 1970), 71, 74-75;

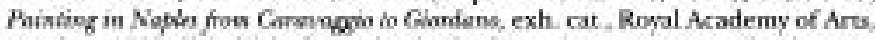

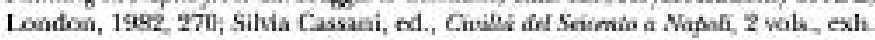
cat, Museo di Capodimonse and Museo Diego Aragona Pignatelli Cortes, Naples, 1944, vol. 1, 123, vol. 2, 45. See thid., wal. 1, 231, for its pendant, the Pines dof Merato dering the Plogur of 1656, Museo Narionale di San Martino. Naples.

6. D. Marnhall, 16.

7. De Dominici, vol. 3, 197; Fillppo Baldinuoci, Notteir bri jeghosori del dínges da Ginofue in qua .... (Florence, 1847; reprint, Farence: S.PE.S., 1974-75). vol. $4,516-17$.

8. Roworth, 220; sev Roworth for the most incisive discussion of this aspect af the pictures.

9. Such as the Alanation sf ste. 5hepbers, $503 / 8 \mathrm{by} 707 / 8 \mathrm{in} .(128 \mathrm{by} 180 \mathrm{~cm})$ Museo e Callerte Nazional di Capodimonte, Naples, Inw. DR \$99, in deposit at the Museo Nacionale di San Martino. Naples, illus. in Sescieri and Dapri. 280-36, cat. no. 102 The picture is documented at the Certosa di San Martino frov 1 1806 and so probalsly forms part of the many pictures ant frescoes coemmissioned from Gargiulo by the Neapolian Carthusians; C Marshall, chap, $15,257-80$,

10. D. Marshall, 170-73, cat. na. WC 68

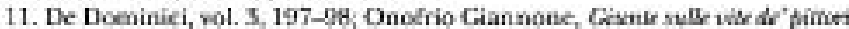
napolatua, ed. Otario Morisani ANaples R. Deputazione di Storia Patria. 1941), $199-40$.

12. The Finol and the Plogue eniered the Museco Reale Borbonico at an uscertain dase and from an uncertain provenance or provenances sametime beneen 1821 and 1852 , while the Eruptisn passed by desecat to is present uuners through various aristocratic Neapolitan collections (Sestien and Dapea, 286-99, 294-96, cat. nos. $140,141,145)$. The issue of provenance is further cumplicated by the fact that the finoll and the Flogur are soutcrimes confused with Coppola's previously discussed painting of the entrance of Don

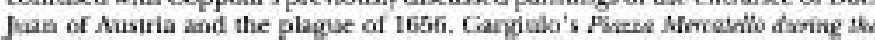
Phyove of 1656 is thus sometimes mistakenly identified as having bees sald by the cavaliere Giosanni Antonis Lambert to the Auseo Reale Borbonico in

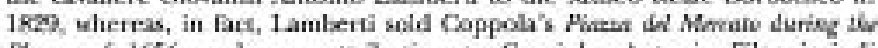
Mague of 1656 . under an ateritution to Gargiulo Antonio Filangieri di Candida "La Galleria Nazionale di Napolh [documenti e ricerche]." La

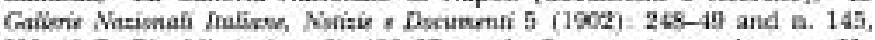
389-40. De Rinaldis (as in n. 5), 426-27, was the first to point out the error. He is certainhy coorect, since the description of the painting sold by Lamberti mentions it as depicting the Piaza del Mertato frather than the Placza Mercavelko, which is depicted in Gargiulo's painting of the plagnei and mestions a wheel for executions, which is prevent only in Coppola's psincing 
The incorrect prosenance of Gargiulo's Pagur continues to be cited in the recent literature (Sectieri and Dapri, 294).

13. Rowurth, 290

14. James Chifton, "Imayes of the Plague and Other Contemporary Events in Sevenieventh Century Naples," Ph.D. disb, Princevon Uabersity, 1987, 175. 144

15. De Dominici /vol. 3, 198) describes painting of an Athock of Tyris by a .5ex Shore and an Anevie of Baxdits is a Fornd which moy be identifiable with owo skirmishes of meta by Cargiulo in the 1690 inventory (ixem 4). Two landscapes with figures and an mals also described to de Dominici may be identifiable in the inventory with heo painting of "wood, sea and cons" (hem 2), while four arekitectural pieces by Codazzi and Garglalo may be identifiable with four "prospetwe," which are atsribueed in the inventory to Gargiulo alone (item 23). 5ee nn. 19, 29, 26 hrion far the ahter piciares mentioned by de Douninici.

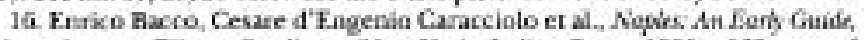
ed. and urans. Eleen Gardiner (New York: Ialica Press, 1991), 132, rev: of

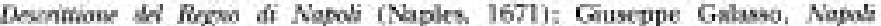

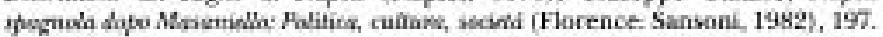
For the Casa Santa dell'Annunzian, see Ciovanni Battista d'Addosio, Orinne,

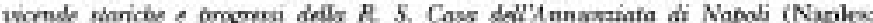

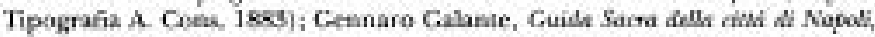
ed. Nicola Spinosa (Naples: Socied Edierice, 1985), 164-67. Gloranni Batton is not mentioned in Candids Conzagi's diucussion of the Procicelli family

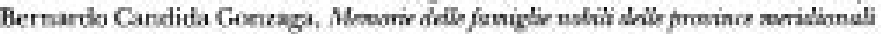
4 Twefie, B wols. (Naples: Tipografia C. de Anpelis, 1875-82), val. 5, 145-47.

17. There are no pictures by Paolo de Matneas, Andrez Belvedere, Clacomo del Po, or others active in the years after the plague. The only posible execptions to this are four pictures by Giovan Battista Ruoppolo and two by Luca Ciordano fitems $8,14,21,221$, but these might zloo date to the 1600.

18. For the predominance of religious painting in Neapolian collections. see Gérard Latrot and Renato Ripoticla, "Pour use enude binorique de la commande arksocratsque dans le royaume de Naples espagnol," Resue Hisoraqu 1 (1980): 27, For the relative infrecoency of mythalogical paintings in Neapolitan collections, ser also Labeot, 57 .

19. Sestieri and Daprz. 74, cat. no. 10; D. Marshall, 158, $411 / 4$ by 531/8 in. $\{105 \mathrm{~cm} 155 \mathrm{~cm}$. The painting trarches boch the dimensions of the inventary reference (jtem 5) and de Dominici's descripton of the painting in Antonio Piscicelli's collection, wol. 3,198

20. Sestieri and Dapra, 74.

21. For the usage of the tern, see Jacogues Callot's Caprioi di varie figure of 1617 , which tho constitaies as important precedent for Garginat Jules Leure, forques Callor, 8 vols, (Paris, Editions de la Gazette, 1924-29\}, cat. nos: 29. $429-741$

22. Dimensious of one by cone and a hall Neapolian polvi (appeca. 10 1/4 by $159 \mathrm{y}$ in. [26 by $40 \mathrm{~cm}$ ]) occur in only 11 of the 281 further imentory

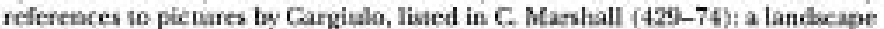
in the early 18th-century collection of Sahanoce Clavarella and an unzuazl series of 10 painting an Cerooese stone in the collection of Roderigo Messia di

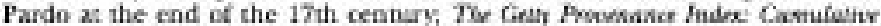
Ediriou on CDFOM (Xalibu: The J. Paul Getry Trust, 1996), Invs. 1-214, 1-154. items 20,21 .

93. Sestien and Daprà, 238, cal no. 104, $123 / 8$ by $173 / 4$ in, (3) s by 45 cms.

24. Artribuved vo Onufrio Palumbo, Mosenielly, Museo Nazionale di San Martino, Naplos, Ins 29re6, illus in Teodoro Fitripalde, ed., II Muse di San Aertine di Nupoll (Naples: Electa, 1995), 78 Jusepe de Ribera, Der fwese of Austria, Patrimonio Nacional, Palacio Real, Madrid, illus, in Alfanso Emilio

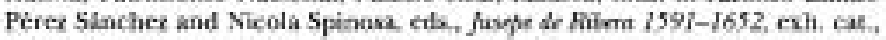
Cautel Sant'Elmo, Naples, 1992.970 , cat. no 1.96.

25. Ruotolo 145-46. For Carrillo's perworality and collection, see also C. Marshall, 528-94.

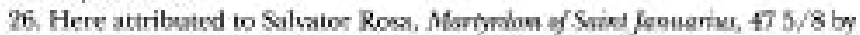

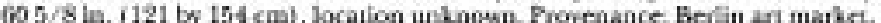
Adolf Gortschewski, 1995 (atrributed to Anjello Falcone); Gattschewski and Schiffer, 1928 (autratuled is Salvalor Rosal); K. Cassirer collection, Rome and Frankfurt, 1928 . It is probably idcntical to the painting in the Firsch collection, Berlin, referred so by Ortolani as by Garsiules Ortalani (as in n.5), 108. The painting compares closely with the sryle, subject, and dimenvions of Rasa's Marfoniva of Seint Lanvesro which is sizmed with a monogram and has been dated by Salerso to the late 1690s. Tolley collectios, Eastbourse. Eno., Luigi Salerno, Samvor Rins (Milan: Edizinni per il Club di Libro, 1965), 141:

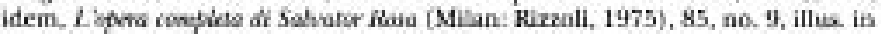
Michael Mahoner, The Dmwines of Sohnies foss, 2 wok. (New York Carland, 1977), tig. 44.1A. De Doeninici's detailied description (vol, 3, 241) accocts bits the pirture in all reipecte: "The knouledgesible Cassliere D. Antonio Piscicello possesses by Rosa the martrdom of Salat Januarius and his companions with a sies of Solfatara taken froen narure which measures five palmi high by six palmi wide (52 by $62 \mathrm{~L} / 4 \mathrm{in}$. 1132 by $158 \mathrm{~cm})]$. The principal figeres, which are tweo palmi high $[207 / 8$ is. $(53 \mathrm{~cm})]$, incluade an ceficial on a white horse in the act of solicixing the decollation and zoother captain on foos wearing armar which appears truly so be of ircon rather than to hime been painted. The backgroend figures make vartous gracious actions and are perhaps even more beautiful thas the principal Ezares."
27. Sestieri and Dapri. 98-41, 286-87, eal Bo, 140, Alfonwo Emilio Péré2

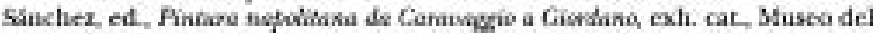
Prado and Palacio de Vilahermosa, Madrid, 1965, 156. There are good reasons to associate the Eroption and the Plagur. Both are signed woth a monogram painted on a stoese that aligns with the paisling vanishing points. a form of signature not encountered elsewhere in Cargulo's oeuve, and the figures in the Erspriow share with the backgronind figures in the Alagor the

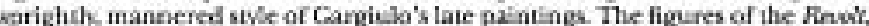
on the other hand, lack the mannered elegance of Gargiulo's late paintings.

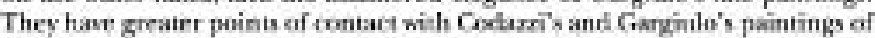

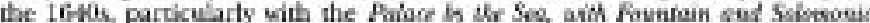
Cramen, which is signed and dated 1647 (D. Manhall, 135-36, cat no. VC 43); compare, for exaenple, the isolwed pair of figures conversing ass gestaring immediately to the left of the ruined ponsument in the center of Prove if Merobo deving the Prosif with the fgures in the center background of Polseg by

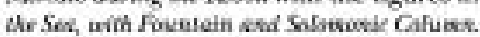

28. De Dominici, vol. 3, 194, 196, 219; Ciannooc (as in n. 11), 139.

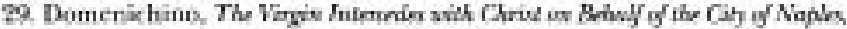
ca. 1651-33, Cachedral of Naples, llius. in Kichard Spear, Eosesichino (Nen Hanen: Yale University Press, 1982), cat no. $109 . \mathrm{i}$

3a. Rowocth, 290.

31. Giuliano Brigandi, Ludovica Treceani, and Laura Laureati, The Bestoca

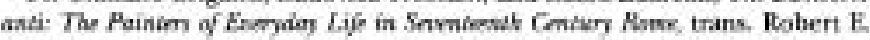
Wolf (Rome: t'go Bozzi, 19e3), 152; Rowarth, 223.

52. Francis Haskell, Patroes and Painter: Art and Sarieny in Barogar haby, rex. ed. (New Hanen: Yale Univerniry Press, 1980), 19 ?

53. Itid: Trezzani in Eiriganti et al. (as in n. 31), 153; D. Marshall, 170, Rroworth. 29s-24.

31. villari, 162 .

35. Ibid

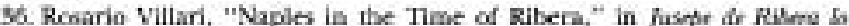
Spsgruktts. 1592-1652, Craig Feltue and William Jordan, exh, cat, Kimbell Art Btuseum, Fort Warth, Tex, 1982, 43.

37. Sestieri and Dapra, 29R, cat no. 144

53. De Dominici, vol. 3, 197, noces of the depictiog of Masanielio and his confederates that they are "so lifelike in their portranal according to the vestimonies of those who witnessed that loeg ragedy. He alwo notes that Masaniello is depicted "as he is decribed by our historians " For the Finnt in the context of early accounts, see also Bartolommeo Capasso, "Masaniello et alcuni di ana famiglia effigiati nei quadri, nelle figure, e nelle stampe del

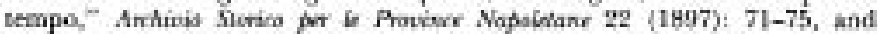
Fiorection, 45

39. For a decalled chrandory of the eveats of the reuple, see Alessindto

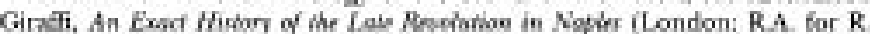

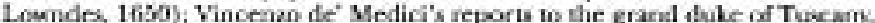
in Palermo, 1846a, 348-53; Cardinal Ascanio Filomariso's dispatches to

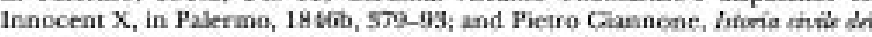
Kowo di Napole ed. Antonio Manongiu (Naples, 1728; reprint. Milan: Maz sorat, 1972). woL. 7, 10-16. Far a recent summary of the events hased on these and other sources, see Burke. 3-2]

w. Burkc, 15 .

4). Thid:i de Dominici, wol. 3. 198

42. Villari, 257 n. 22. Rosario Villart. "Piara Mercano 10 heyio 1647," in Napoli. Eves stivis per inusagiei (Naples. Gaetano Macchiaroli, 1965), 318.

13. As, for example, in the painting attribuoed to Onodrio Pahmbo, where Macaniello x'so displais the bason and bearing of a getueral (Fincentina 46) For other insances, see Aurello Busi ed., Masescino (Naples: Hiso de Rosa, 1994), passim.

44. Letter from Cand nal Ascanlo Filomanno to Lneocent X, July 12, 1647, is Piermo, 1846b, 385

45. Ibid., sss-86; ienter from Vincenas de' Medici wo the Crand Duke of Twesank July 13, 1647, in Palermo. 1846is, 348-49.

46. Ibid., 319 .

47. Pariroppe Parifinata act 1, quoted in Palermo, 1846a, 363.

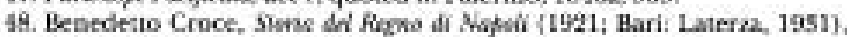

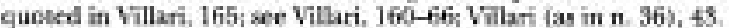

49. Vilart, passim. esp. 84, 184-37, 143-14; Elliot \{as in n. 1), 109-30, esp. $124-27$

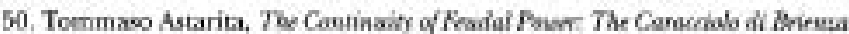

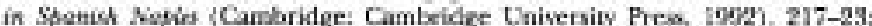

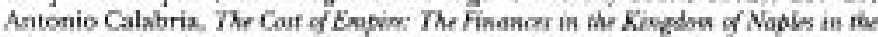
Thus of the Spanist Ruie (Cambridge: Cambridge Unîersiģ Press, 1991), 39-47. valuri, ga-ion

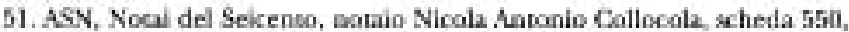
protocollo 20 , foll. 750 , E. Iv-litr. allegati al $6.760 \mathrm{e}$.

52. For the equation of one docat to 20,000 lire, see Ferroando de' Rossi and

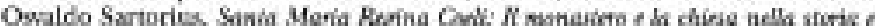
neITarix (Naples: Edikariale Scientifica, 1987), 191. For parments to stonecatters at the Certosa di San Martino sec. ASN, Monasteri soppressi, vol. 21 49, fols. S7r-v and 98c. For the price of borses, see Nanzio Federigo Faragliz. Sharia dri

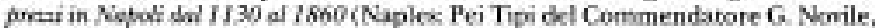
$1878), 218-19$

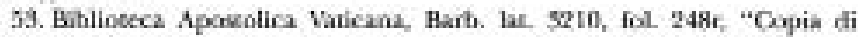
Jettera del Macto di Campo Otiariano 5auli, An'Ece mo $5 x$ Marchese Spinola 
a Cesosa"; Savil's letters fminus this list) were subsoguently pablished as "Relazione dei turmule napoletani del t647," in L Correra, ed., Andtúo Sarric tor 6 Provina Napohtan 15 (1890): 955-87

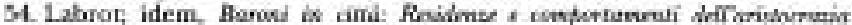
espoktres, 1530-1734 (Naples: Socied Edience Napoletana, 1979): idem,

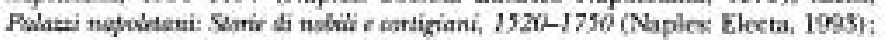
Renate Ruosola, "Aspetti del collezionismo napoletano del Seicesto," in

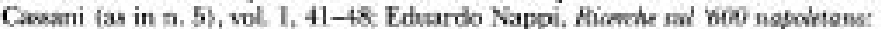

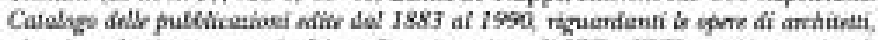

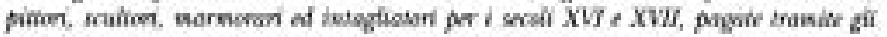
axtichi Aunrki mubsüri notroberei (Milan: L. \&. T. 1992)

50. See the investory of the collection of Cionanna Battiva Aragona Pignaselli, dochess of Terranosa e Monteleone, Naples, Seps. 30, 1725, in Laterst, Itw. 6i], isems $154,155,317$.

66. Candida Gonaga (as in n. 16), vol. L. 184.

57, A second Ettore Pignaselli attained the high-ranking military position of

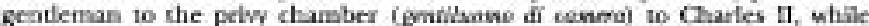
Nicola Pignatelli was viceroy of Sardiniz znd dose advisor (esnsiglier ietreno) to bou, Chates II and Philip V; ihid, 184-86

58. Ruscalo, 145-16.

50. De Dominici, vol. 3, 194.

61. Capecelatro commisioned a mosacte of the innocents from Cargiulo in 1686 and paid him for additional paincings in 1658: Eduardo Nappl. "Pietreri del '600 a Napoli: Notizie incedite dai doctumenti dell' Archinio Storice

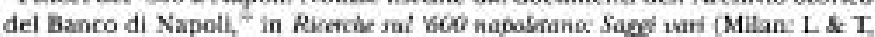

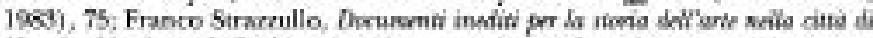
Napatí (Naplesx II Fudars, Seabilmenta Tipografico Cienzaro d'Aqootine, 1950). 49-44. The inveatories of his possessions compiled in the 1656 , one of which is th Cargialo himself, concain ntamerous referestes to painting by Gargiulo and his asociates; Lahrot, 10]-1, 113-15, Ins. 16, 19. For Capecelat ro's collection and asociation with Gargieko, see Lakrot, 101; and C. Manhall. $311-17$.

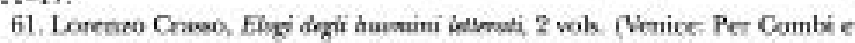

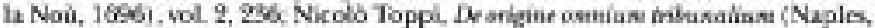
16699 . wol. 2, $545-47$.

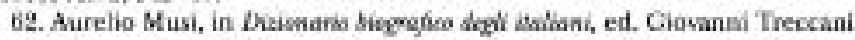
et al., vol. 18 \{Rome; Intituto drila Encicloperia ltafiana. 1975?, 41

63. Ruocolo, 1 te.

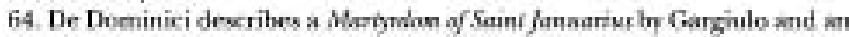
unspecified number of prospotriov by Codazi and Gangiulo in the collection a the prince of Ave Iline (vol. 9, 192 201). His description ix corroburated tor the paintings by Codacei and Cargiulo that are listed in inveneories of the collection of the prince of Avelliso compiled in 1600 (in which, unforturatedy. only a small proportion of the paintings are atributed f and in the nineteench century, Herano Rusolo, "Astisti, dotiori e mercanti napoletani del socondo

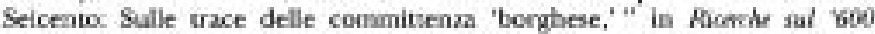
napohiane (Milan: L \& T, I947), 183 n. 32; Doe Ferrante [Gaseppe Ceci of Benedetto Croce), "La quadreriz dei principi di Avellino," Nopoll Nobinissine 11, no. 10 (1902): 159.11, no. 11 (1906) : 175. For the progoved identification of the original oumer of these works as Francesco Marine Caraceiolo, prince of Avellino, *xe n. 75 below and C. Marshall, $341-45$.

65. Dizismario diogorfice izs in n. 69), vol. 19 (1976), 363

6iti, C. Markhall, 252-91. Cargiulo consulted with him regarding the collettion of the Neapolitan connoisseur Giowan Camillo Cacace

67. Craseo (as in n. 61), vol. 2, 307 .

68. Labroc 75-78. Inv. 9

f9. For the political sympathies of Ferranate Spinelli, prisce of Tarsia, see Fritz Saxd, "The Battle Scene without a Hero: Aniello Falcone and Hit

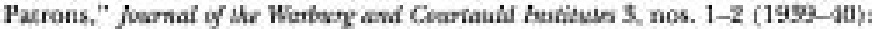
83-94.

70. For d'Andrea's collection and eareer, see Vincenzo Pacelli, "La quadre

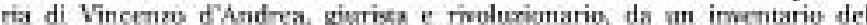

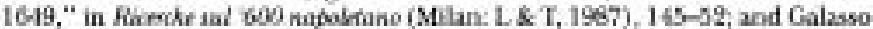
(as in n. 16), 5, 97-98

71. Sestieri and Daped, 48, Maria Causa Picone, Mosm napoinawi dod St

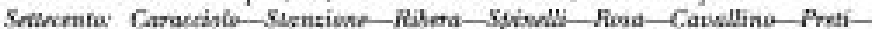

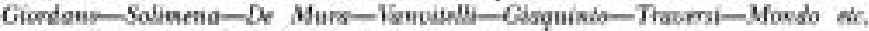
(Florence Lstitato Alinari, 1959), 30, cal. no. 19.

72. Sestieri and Dapra, 69. See also Amanid Brtion de Lavergnte et al., eda.

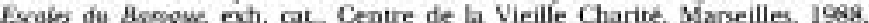
182-84, eal. no. 53 Tae related preparatory drawing a one of a group in the Musee des Beanasres, Orleans, which wa first identified and discussed by

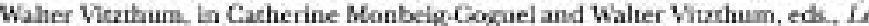

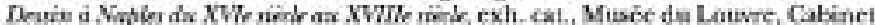
des Dessins, Paris, 1967, 94. Brejoo de Lavergnee identified one of the drawings as preparasory foe the Saike l.my Bing Led as Hes Merryobso (Muske de FOise Resurais, inv. no. 61.10) and publisherl photographs of vome of the others, in "Auvour de Falcone. de Rosa et de Micco Sadaro Quelques ableaux napoliazins conserves dans les musées de prosince Irancais, "In Sicrim

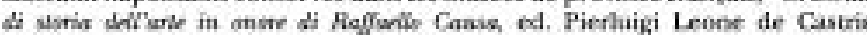
Ailan Electa, 19681, 199, 202, figs, $16,17,18$

73. The painting is one of a series of tour described by de Dominici. rol. 3 ,

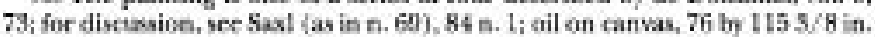
$199 \mathrm{br} 293 \mathrm{~cm}$; private collection. Rnme; published with the trite Cassind

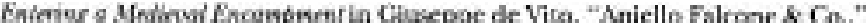
in Fiowher sul' 600 ngpobrons (Afilan L. \& T, 1989), 15, figs. 18-20. The peresent title follows that given in 1877 when the painting, then still in the possession of the Caractiolo di Arellino family, was included in a lean exhibition of Nrapolitan art: Salazaro and Flangieri (as in n. 5), 120, cat. no. 67. The dimensions giren in the catakigue match those of the present work as well as those in the 1844 iswentary of the callection of the prince of Avelling: Ferrante (as in n. 64), 174: "18. A painting on canvas depicting a metieval encampenent with numerows figures including a cardinal on borseback [ 7 by 11/4 palmi) [aporos. $721 / 2$ by $1215 / 8$ in. $[184$ in $309 \mathrm{~cm})]$ by Aniello Faloone, 60 ducats." For Marino Aveanio Caracciolo (14m-1538), see G. de Caro, is Dizimaris figgrofim fas in N. 69), vol. 19 (1956), 414-25; and Astariba (as ia A. 50), 27-29, who places Marino'x career in the context of his farnih mecriben' efforts to attain comparable positlons within the Spanish adminikera. tion.

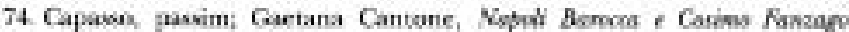
(Naples: ESI for Hanco di Napoli, 1984), 420-21,

75. Capasso 114-15.

76. For the size and placement of the second trinamie, see ibld., 116-17, quoting Polita, "Histora di Nap. Fivolus del 1647," ma, Biblioteca Narionale, Naples, fol 60; and ibid., 117, quotieg Molini, "La vera sollevazione di Masaniello," ms. Biblioteca Universitaria Bologna, fol. 261. For the locatioes of the fint pitofin which was placed toward the northern end of the Mercavo, see ibid. 114 .

77. Ibid, 189

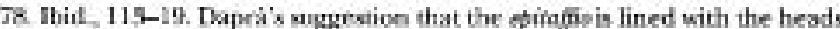
of the leaders of the revolt has been corrected ty villari $[257 \mathrm{n}, 22)$ and Fiocentino $[\mathrm{H}]$.

79. An has alw been noted by Roueorth, 278

8. De Daminici (vol. 3, 198) jentifies ane of these figures as a "cappa nera," for which, see Giuseppe de Blasiis, "Le giusticie eseguine in Napoli al

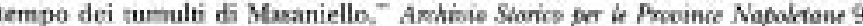
(1844): 125 a. 2. For this sole of clathing sce who Adelaide Cirillo Mastrocingae, "Moda e costume," in Sronia di Nopoit, wol. 6 (Naples: Societa Exlitrice, IIt70), 778-80.

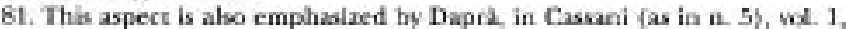
300

84. Burke, 14.

83. Letter from Cardinal Ascario Filomarino to Innocent $\mathrm{X}$-July 8, 1617, in Palerma, 1846h, 391.

84. For della Porta's account of the revoln, see Burke, b-7.

85. Thit 5-?

86. De Dominici, wh 3, 194.

87. For the traditional dichotomy between the dignity of hivoory painting and the iquohiliry of gener painting, ser Parry Wird. "Cente Somse Problems and Percepions," Geare in the Aly of the Baragee A Feroure Guide (New Yark. Cartand, 1991), xvi-xail. For the soveciation of genre inagery with barleogue comedy, see Mina Gregori, "Nuosi accernamend in Toscana sulla pietura

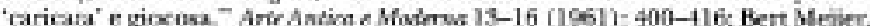
"Esempi del comico figurativa nel Kinascimento lambariko," Ars lumberie 1 fi (1971): 250-66. Barry Wind. "Tieture Ridicole: Some Late Cinquecento

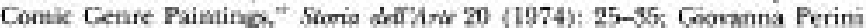
"Cenre Painting in Eighteenth Cenoury North Italian Art Collections and Art

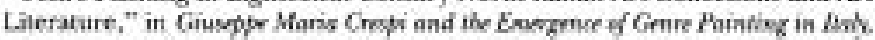
ed. John T, Spike, exh. cat., Bumbell Art Maseum, Fort Worth, Tex., 1955, B. 1 85

B8. Trisuph of Duvid, John and Mahle Kingling Museum of Ant, Sarwota. Fla, Inv SN 155; Fuic Suseo Correale di Terranowa, Sorrenan; Sesuieri and Daped, 87-88, 67-68, cat, nos, 20, 5.

89. De Dominici, wol. $8,197-98$.

90. Dhit., 198 .

91. Itaid., 212, quoting Prolo de' Matteis, "notizie di alcumi pitnori. ..." ms. ta. 1720. For the critical stanos of de' Nattcis's mantacript see Thomas Willette, "Bernardo de Dominicl e le Vie de pietod, scultoori ed architeti napoletani: Contributo alla riabilitazione di una fonte," Fironke sol " 600 .

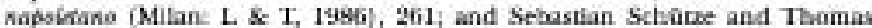

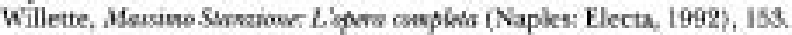

92. For interpreations of the painting, see Gino Dariz, II. Muso $r$ is Cotoie of

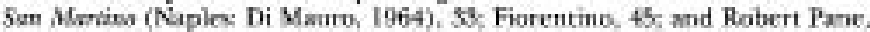

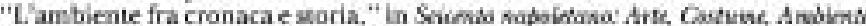
(Milan: Fdirione di Comunità, 1984), 4. For the crows of false goid, sec Burke. 13

93. For contemporary acrounts of the exrcution of Doen Cinseppe Carafa.

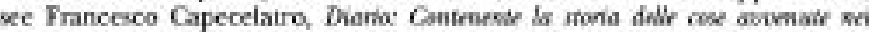

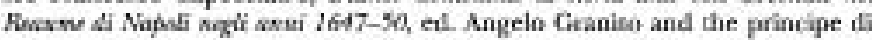
Bclmonie, 3 vols, (Naples: G. Nobile, 1850-54), vol. 1. 56-58; and the letter of the Genoese ambasadoe to Naples, Aag. 3, 1647, in Correra ias in a. 53). $565-64$.

94. Boworth, 221; Daprd (as in n. 81), vol. 1, 299, Dapr2, in Sesilert and Dapeà, 290 , camments on "Ihe modernify of the framing of the compowition, which has been conceived almost as a phoograph, in order to docament a precise momest in a particulaz hiveric evene."

95. Sestieri and Dapra. 245, cas no. 169 


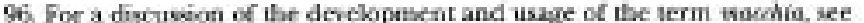
Pailip Sohm, "Macedia: Order or Disorder?," in Pinoreces Marcp Buschind, Has

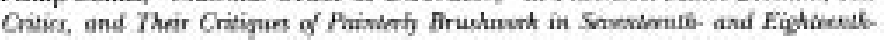
Coutury Phis (Cambridye: Cambeldye Universiry Press, 1991), 36-43

97. Enrice Crispolti, "Pantasy," in Exrybopidie of Wirld Art (New York: McGraw-Hill, 196i1), wol, 5, 357.

98. Sohm tas in $n .96), 36-43$

92. Puirke, 12-13. Causa makes a similar obiervation about the procesion when be notes, "The populace ernuds the procession without participating. Only the nohility, the teliginus ouders and the viceron maintain the digaity of class that allows them to follous the ampullae of the blood of Saint lanu-

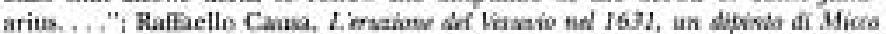
Spadme ed as paenutso di G. B Anzamere (Naples: L'Arte Tipografica, 1956), n.p.

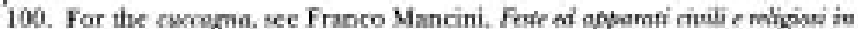

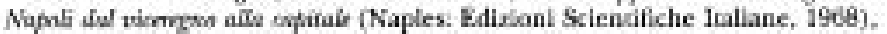
$31-32,88,91-94,170-71$. For 17 th and 18 th-century descriptions of the

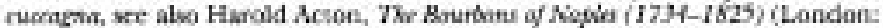

Methuen, 1956), 49-44: Franco Mancini, - 'L'immaginario di regime't Apps. raci e scenografie alla corte del vicene," in Cassani (as in n. 51, wol. 2, 31-92;

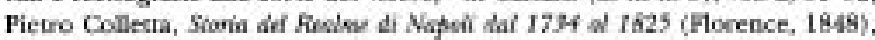
quoted in Desmond Senard, el., Napks. A Thuxibs' Companawe (London: Consable, 1984), 140-41.

101. Woligang Prohaska and Nicola Spinosa, eds, Setteronis napaktane: Stü̈

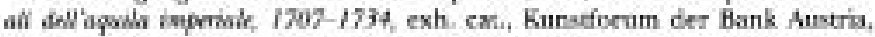
Vienna, and Castel Sant'Elmo, Naples, 1995-94, 136, cat no, 3a; Elio Catello,

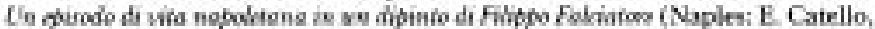
1993), passim; and Roberto Middiooe and Brigitte Dapric eds, Neaùà e, fontasss shlia putrars nepoltane $(X V W-X X X$ serabs exh. cat., Institut Culturel Italien. Paris, 1947, 16-67. Antonio Joli also depicted the carrogne on occasion, sech as Cucragne is the Largo di Paimer, Lord. Montagu of Beautien collection,

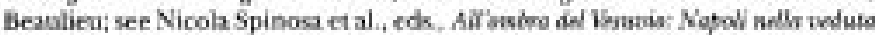

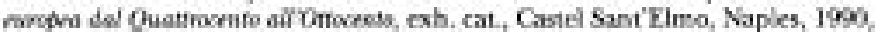
196, 400. Alwo of interest is the series of ten engravings of the nockime della rarcegna of 1729-34: Prohaska and Spinosa, 351-59, cat. no 129.1-10. 


\section{University Library}

\section{- M M I N E R VA A gateway to Melbourne's research publications}

Minerva Access is the Institutional Repository of The University of Melbourne

Author/s:

Marshall, Christopher R.

Title:

"Causa di stravaganze": order and anarchy in Domenico Gargiulo's Revolt of Masaniello

Date:

1998

Citation:

Marshall, C. R. (1998). "Causa di stravaganze": order and anarchy in Domenico Gargiulo's

Revolt of Masaniello. The Art Bulletin, 80(3), 478-497.

Publication Status:

Published

Persistent Link:

http://hdl.handle.net/11343/34867 